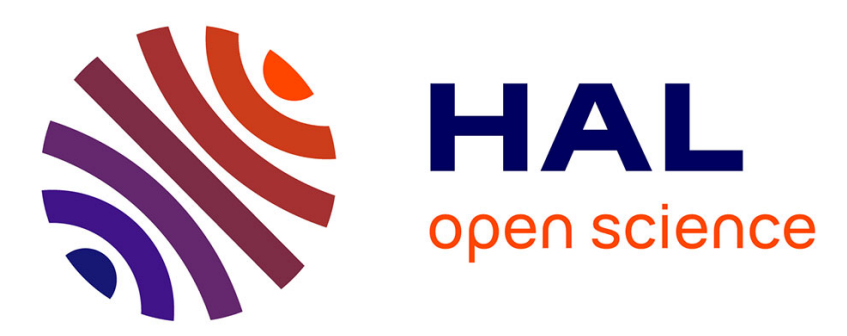

\title{
Innovative conditioning of algal-based sorbents: Macro-porous discs for palladium sorption
}

Shengye Wang, Thierry Vincent, Jean-Claude Roux, Catherine Faur, Eric Guibal

\section{- To cite this version:}

Shengye Wang, Thierry Vincent, Jean-Claude Roux, Catherine Faur, Eric Guibal. Innovative conditioning of algal-based sorbents: Macro-porous discs for palladium sorption. Chemical Engineering Journal, 2017, 325, pp.521 - 532. 10.1016/j.cej.2017.05.103 . hal-01670273

\section{HAL Id: hal-01670273 \\ https://hal.umontpellier.fr/hal-01670273}

Submitted on 20 Nov 2020

HAL is a multi-disciplinary open access archive for the deposit and dissemination of scientific research documents, whether they are published or not. The documents may come from teaching and research institutions in France or abroad, or from public or private research centers.
L'archive ouverte pluridisciplinaire HAL, est destinée au dépôt et à la diffusion de documents scientifiques de niveau recherche, publiés ou non, émanant des établissements d'enseignement et de recherche français ou étrangers, des laboratoires publics ou privés. 


\title{
Innovative conditioning of algal-based sorbents: Macro-porous discs for palladium sorption
}

\author{
Shengye Wang ${ }^{\mathrm{a}}$, Thierry Vincent ${ }^{\mathrm{a}}$, Jean-Claude Roux ${ }^{\mathrm{a}}$, Catherine Faur ${ }^{\mathrm{b}}$, Eric Guibal ${ }^{\mathrm{a}, *}$ \\ ${ }^{a}$ Ecole des mines d'Alès, Centre des Matériaux des Mines d'Alès, Pôle Matériaux Polymères Avancés, 6 avenue de Clavières, F-30319 Alès cedex, France \\ ${ }^{\mathrm{b}}$ Institut Européen des Membranes-IEM (UMR 5635 CNRS-ENSCM-UM2) - Equipe Génie des Procédés Membranaires, Université de Montpellier cc047, Place Eugène Bataillon, \\ 34095 Montpellier Cedex 5, France
}

\section{H I G H L I G H T S}

- Alginate and algal-based discs were prepared using one pot synthesis procedure.

- A new fixed-bed like system was proposed for palladium recovery.

- Crosslinked polyethylenimine greatly improved sorption capacity of algal discs.

- New functional groups were brought in after desorption using acidic thiourea.

- Sorbents can be regenerated at least 4 times without losing binding affinity.
G R A P H I C A L A B S T R A C T

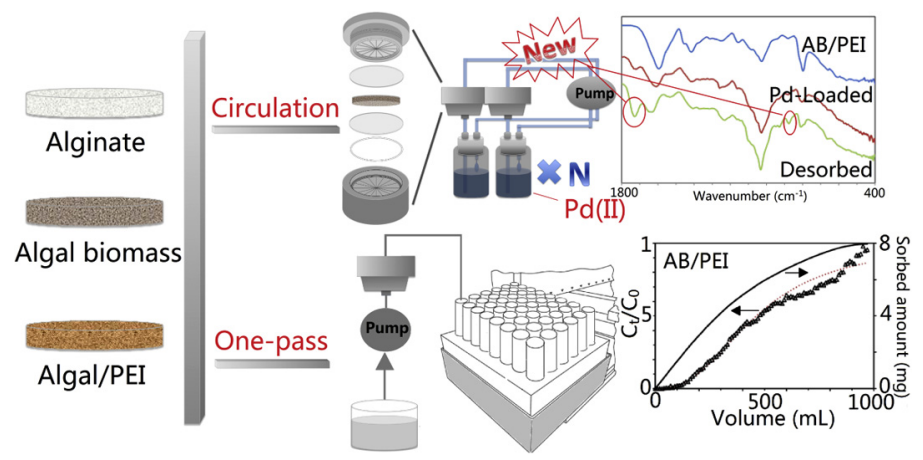

\section{A B S T R A C T}

Algal biomass $(\mathrm{AB})$ was used for green synthesis of porous discs by one-pot extraction and shaping procedure without adding pure alginate. Glutaraldehyde-crosslinked polyethyleneimine (GLA-PEI) was incorporated into $A B$ discs. These two sorbents $(A B$ and $A B / P E I)$ along with alginate discs (as a reference) were applied in a fixed-bed-like system using a recirculation mode or a single-pass flow mode for palladium recovery. Recirculation experiments show that the incorporation of $9 \%(w / w$, dry weight) GLA-PEI remarkably improves (more than 100\%) sorption property for $\mathrm{Pd}(\mathrm{II})$. The flow rate $\left(5-45 \mathrm{~mL} \mathrm{~min}{ }^{-1}\right.$ ) hardly affects the sorption rate regardless of sorbent type. The pseudo-second order rate equation well fits the kinetic profiles. Sorption isotherms of $\mathrm{Pd}(\mathrm{II})$ onto alginate and $\mathrm{AB}$ discs are well described by the Langmuir equation, while the prediction of that onto AB/PEI sorbent requires the Sips model with a larger number of fitting parameters. The maximum experimental sorption capacity is $46.8 \mathrm{mg} \mathrm{g}^{-1}$ for alginate, $56.9 \mathrm{mg} \mathrm{g}^{-1}$ for $\mathrm{AB}$ and $121.6 \mathrm{mg} \mathrm{g}^{-1}$ for $\mathrm{AB} / \mathrm{PEI}$ discs. The so-called Yan equation fits well the data obtained from single flow experiments. The Pd-loaded discs can be desorbed using $2 \mathrm{M} \mathrm{HCl} / 0.1 \mathrm{M}$ Thiourea as the eluant with desorption efficiency approaching 100\%. FTIR analysis confirms that after desorption, the sorbents are chemically modified: thiourea brings amine groups, which improve $\operatorname{Pd}(\mathrm{II})$ binding in the next sorption cycle. Sorption/desorption experiments show that all the sorbents can be reused for at least 4 times with a concentration factor (CF) of 7.9-8.4, 7.8-8.1 and 4.2-6.3 for alginate, $\mathrm{AB}$ and $\mathrm{AB} / \mathrm{PEI}$ discs, respectively in the recirculation mode, while CFs in single-pass mode are $5.8,4.4$ and 6.1 for alginate, $\mathrm{AB}$ and $\mathrm{AB} / \mathrm{PEI}$ sorbents, respectively.

Keywords:

Porous algal disc

Palladium

Sorption

Breakthrough columns

Desorption

Recovery

\footnotetext{
* Corresponding author.

E-mail address: Eric.Guibal@mines-ales.fr (E. Guibal).
} 


\section{Introduction}

The recovery of valuable metal ions (i.e., precious or strategic metals) and the removal of hazardous metal ions (i.e., heavy metals) are becoming critical challenges for industry due to environmental regulations and incentive politics for metal recycling from waste materials and manufacturing processes. Concentrated effluents may involve precipitation or solvent extraction process for metal recovery [1,2]; however, for dilute effluents sorption may be preferred using for example chelating or ion-exchange processes [3], extractant-impregnated resins [4,5], extractantimpregnated supports [6-8], polymer inclusion membranes [9], or hybrid organic/inorganic sorbents [10-12]. Biosorption may represent an interesting alternative to these conventional sorbents since these materials are renewable, more environmentally friendly (especially at the end of their life cycle; the thermal degradation of the sorbents produces less toxic residues than synthetic resins) and they bear similar reactive groups to those found on synthetic resins. Their physico-chemical stability may be less than that of synthetic resin in harsh environments; however, for mild experimental conditions, biosorbents can be competitive for the recovery of metal ions from dilute effluents. Biosorbents may be obtained from agriculture sub-products [13-18], or from marine feed-stock [19]. Biopolymers such as chitosan [20-24], and alginate have been widely investigated for metal sorption [25,26]. The abundant functional groups such as carboxyl, hydroxyl, sulfate and amine groups on these sorbents are considered to play a predominant role in the binding of metal ions. Due to their easy dissolution in many aqueous media (e.g. chitosan in dilute mineral acids, except for sulfuric acid and alginate at alkaline or neutral $\mathrm{pH})$, these biopolymers are stabilized through crosslinking treatment. The main drawback at using these materials is associated to their extraction/ purification processes; indeed more reagents are used and poorly valorizable residues are produced: this means environmental impact and increase in the cost of the sorbents.

Very recently, a novel method has been proposed for the preparation of algal beads and relevant composites through a one-pot extraction and shaping of alginate fraction of the algal biomass: the process was used for preparing algal-biomass beads and composite sorbents (associating algal biomass and glutaraldehyde cross-linked polyethyleneimine (GLA-PEI)) without adding encapsulating agent [27-29]. This environmental-friendly method consists of the mild-alkaline extraction of alginate-based compound from the algal biomass and the further distribution of the asprepared suspension into an ionotropic gelation solution, avoiding using chemical agents for purification process. Moreover, the incorporation of GLA-PEI significantly improves the sorption capacity of this green material for Pd(II) and Pt(IV).

The application of highly macro-porous sponges/foams has been widely applied in drug delivery system [30], growth of biological cells [31], but also in the treatment of contaminated water [32]: the reaction taking place in the sponge before a wringing step expediently removes decontaminated water and concentrate the toxic metal in the support. These materials are characterized as highly macro-porous supports with high percolating properties that can be easily used as reactive filters in a fixed-bed system [33,34].

In this work, the concept of "one-pot synthesis" is used for preparing algal biomass and GLA-PEI composite (AB/PEI) discs that will be used for the recovery of $\mathrm{Pd}(\mathrm{II})$ and the sorption properties are compared with the sorption behavior of alginate and algal biomass $(\mathrm{AB})$ discs. A fixed-bed like system is developed: metal is adsorbed by pumping the metal ions solutions through the immobilized foam discs using a recirculation mode and desorbed right after the sorption process. The sorbents are also tested in a continuous system. Specifically, this study focuses on the: (1) characterization of the foam discs (raw and after sorption/desorption) using FTIR spectroscopy and scanning electron microscopy (morphology) and SEM-EDX (energy dispersive X-ray) analysis (map distribution of elements); (2) sorption of $\mathrm{Pd}(\mathrm{II})$ : effect of velocity, sorption kinetics and sorption isotherms; (3) desorption of $\mathrm{Pd}(\mathrm{II})$ : effect of desorption agents and contact time; (4) sorption-desorption cycles (reuse of the sorbents and concentration of Pd(II)); (5) continuous sorption and desorption of $\mathrm{Pd}(\mathrm{II})$ in a single-pass mode with a slow flow rate.

\section{Materials and methods}

\subsection{Materials}

Laminaria digitata is a brown alga; it was supplied by SETALG (Pleubian, France). The biomass was first washed, dried at $50{ }^{\circ} \mathrm{C}$ overnight, grinded and sieved (the fraction $<250 \mu \mathrm{m}$ was used). The procedure described by McHugh [35], and slightly modified by Bertagnolli et al. was applied for characterizing the alginate content in the biomass [36]: L. digitata contains about $31 \%(\mathrm{w} / \mathrm{w})$ of alginate. Alginate was supplied by FMC BioPolymer (USA) (commercial reference: Protanal 200S). The fractions of mannuronic (M) and guluronic $(G)$ acids in the alginate were determined by NMR analysis [37]. In alginate extracted from $L$. digitata the $M / G$ fractions were $0.62 / 0.38$ (compared to $0.37 / 0.63$ for alginate reference material; i.e. Protanal 200S).

Branched polyethyleneimine (PEI, water free, low molecular weight: $600-800 \mathrm{~g} \mathrm{~mol}^{-1}$ ), calcium carbonate and glutaraldehyde (50\% $(w / w)$ in water) were supplied by Sigma-Aldrich (Taufkirchen, Germany). Other reagents such as sodium carbonate, formic acid and calcium chloride were supplied by Chem-Lab NV (Zedelgem, Belgium). Palladium(II) chloride was supplied by R.D. $\mathrm{H}$ (Germany). The stock solution was prepared by dissolving $10 \mathrm{~g}$ of palladium(II) into $1.1 \mathrm{M} \mathrm{HCl}$ solution.

\subsection{Synthesis of macroporous discs}

Crosslinked PEI was prepared by mixing $45 \mathrm{~g}$ of PEI with $45 \mathrm{~g}$ of glutaraldehyde (GLA) solution (50 wt\%) into $500 \mathrm{~mL}$ pure water. After fast agitation, the mixture was maintained for $24 \mathrm{~h}$ at room temperature to complete the crosslinking reaction. Thereafter, GLA-PEI was washed, filtrated, freeze-dried and sieved (200 mesh).

Ionotropic gelation was applied for the preparation of pure alginate discs but also for the gelation of alginate extracted from algal biomass (for $A B$ and $A B / P E I$ discs). A certain volume $(600 \mathrm{~mL})$ of alginate solution $(1 \%, w / w)$ or suspensions $(A B$ or $A B / P E I$ composite) was firstly homogeneously mixed with $20 \mathrm{~mL}$ of $\mathrm{CaCO}_{3}$ suspension $(1 \%, w / w)$. Then the mixture was added into the molds $(\mathrm{d}=50 \mathrm{~mm})$, stored in a freezer at $-80^{\circ} \mathrm{C}$ for $1 \mathrm{~h}$ and freezedried $\left(-52{ }^{\circ} \mathrm{C}, 0.1 \mathrm{mbar}, 48 \mathrm{~h}\right)$. The dried discs were immersed in a solution containing both $\mathrm{CaCl}_{2}(1 \%, \mathrm{w} / \mathrm{w})$ and formic acid (1\%, $\mathrm{v} / \mathrm{w})$ under shaking $(20 \mathrm{rpm})$ for $24 \mathrm{~h}$, washed 4 times with $4 \mathrm{~L}$ (in total) of pure water and freeze-dried $\left(-52{ }^{\circ} \mathrm{C}, 0.1 \mathrm{mbar}, 24 \mathrm{~h}\right)$.

Specifically, the algal biomass suspension was prepared by adding $15 \mathrm{~g}$ of $L$. digitata (dry) and $3 \mathrm{~g}$ of $\mathrm{Na}_{2} \mathrm{CO}_{3}$ into $576 \mathrm{~mL}$ of pure water. The mixture was then maintained at $50{ }^{\circ} \mathrm{C}$ for $24 \mathrm{~h}$. AB/PEI suspension was obtained by mixing $1.5 \mathrm{~g}$ (dry-weight) of GLA-PEI into the prepared algal biomass $/ \mathrm{Na}_{2} \mathrm{CO}_{3}$ solution. All other steps are similar to the procedure followed for alginate material.

\subsection{Characterization of materials}

FT-IR spectrometry analysis was performed in the range 4000$400 \mathrm{~cm}^{-1}$ using an FTIR-ATR (Attenuated Total Reflectance tool) Bruker VERTEX70 spectrometer (Bruker, Germany). The discs were loaded with $\mathrm{Pd}(\mathrm{II})$ by contact at $\mathrm{pH} 2.5$ (controlled by $1 \mathrm{M} \mathrm{NaOH}$ or 
$\mathrm{H}_{2} \mathrm{SO}_{4}$ ) of a $\mathrm{Pd}(\mathrm{II})$ solution (v: $100 \mathrm{~mL} ; \mathrm{C}_{0}: 200 \mathrm{mg} \mathrm{Pd} \mathrm{L}{ }^{-1}$ ) with $50 \mathrm{mg}$ of discs for $48 \mathrm{~h}$. For the analysis of sorption/desorption effects the sorption was operated using $25 \mathrm{mg} \mathrm{Pd} \mathrm{L}^{-1}$ solutions (sorbent dosage, SD: $250 \mathrm{mg} \mathrm{L}^{-1}$ ), while the discs were desorbed using $200 \mathrm{~mL}$ of $2 \mathrm{M} \mathrm{HCl} / 0.1 \mathrm{M}$ thiourea solutions.

Scanning electron microscopy (SEM) and SEM-EDX (SEM coupled with energy dispersive X-ray diffraction analysis) were performed using an environmental scanning electron microscope Quanta FEG 200 (FEI France, Thermo Fisher Scientific, Mérignac, France), equipped with an Oxford Inca 350 energy dispersive Xray micro-analyzer (Oxford Instruments France, Saclay, France).

The $\mathrm{pH}_{\mathrm{ZPC}}$ of the discs was measured by titration method [38]. One hundred and fifty $\mathrm{mg}$ of sorbent were mixed with a $0.1 \mathrm{M} \mathrm{NaCl}$ solution for $48 \mathrm{~h}$; the initial $\mathrm{pHs}\left(\mathrm{pH}_{0}\right)$ were varied between 2 and 8 , the final $\mathrm{pH}\left(\mathrm{pH}_{\mathrm{eq}}\right)$ was recorded and plotted against initial $\mathrm{pH}$; the $\mathrm{pH}_{\mathrm{ZPC}}$ corresponds to the $\mathrm{pH}$ where the plot crosses the first bisectrice (i.e., $\mathrm{pH}_{\mathrm{eq}}=\mathrm{pH}_{0}$ ).

The apparent density and porosity of the foams were characterized by pycnometer measurements using ethanol as the soaking agent. Two different processes were tested using either foam discs (as produced) and geometrically cut materials (measuring the dimensions with a vernier caliper).

\subsection{Sorption experiments}

The foam discs were immobilized in a filter membrane holder (Swinnex, Ø $25 \mathrm{~mm}$, Millipore, Merck Chimie SAS, Fontenay sous Bois, France). The metal-containing solution was pumped through the reactive disc filter via a recirculation mode for $48 \mathrm{~h}$ for obtaining sorption isotherms. The sorbent/solution ratio was $1 \mathrm{~g} \mathrm{~L}^{-1}$ (dry weight, d.w.; sorbent mass, $\mathrm{m}(\mathrm{g})$ and volume of solution, $\mathrm{V}(\mathrm{L})$ ) for alginate and $\mathrm{AB}$ discs and $0.5 \mathrm{~g} \mathrm{~L}^{-1}$ for $\mathrm{AB} / \mathrm{PEI}$ sorbent, and $\mathrm{Pd}(\mathrm{II})$ concentration (i.e., initial metal concentration, $\mathrm{C}_{0}, \mathrm{mg} \mathrm{Pd} \mathrm{L}^{-1}$ ) was varied between 20 and $150 \mathrm{mg} \mathrm{Pd} \mathrm{L}^{-1}$. Samples were collected at equilibrium and analyzed for residual metal concentration $\left(C_{e q}\right.$, $\mathrm{mg} \mathrm{Pd} \mathrm{L}^{-1}$ ), after filtration, by inductively coupled plasma atomic emission spectrometry (ICP-AES, JY Activa M, Jobin-Yvon, Horiba, Longjumeau, France). The sorption capacity (q, $\mathrm{mg} \mathrm{Pd} \mathrm{g}^{-1}$ ) was calculated by the mass balance equation: $\mathrm{q}_{\mathrm{eq}}=\left(\mathrm{C}_{0}-\mathrm{C}_{\mathrm{eq}}\right) \times \mathrm{V} / \mathrm{m}$.

The flow rate was varied for the study of uptake kinetics between 5 and $45 \mathrm{~mL} \mathrm{~min}^{-1}$ (i.e., superficial velocities: 0.6, 3 and $\left.5.5 \mathrm{~m} \mathrm{~h}^{-1}\right)$. The sorbent dosage for uptake kinetics was set at $0.2 \mathrm{~g} \mathrm{~L}^{-1}$ (Pd(II) concentration set to $\left.20 \mathrm{mg} \mathrm{L}^{-1}\right)$. Samples were collected along uptake kinetics, filtrated and analyzed by ICP-AES for evaluation of residual metal concentration $\left(\mathrm{C}_{\mathrm{eq}}\right)$.

For the study of metal desorption the discs that were previously loaded with $\mathrm{Pd}(\mathrm{II})$ were put into contact with the desorption agent ( $2 \mathrm{M} \mathrm{HCl}, 5 \mathrm{M} \mathrm{HCl}, 0.1 \mathrm{M}$ thiourea and $2 \mathrm{M} \mathrm{HCl} / 0.1 \mathrm{M}$ thiourea solutions) in the same recirculation mode (flow rate $5 \mathrm{~mL} \mathrm{~min}^{-1}$ ). Samples were collected at different contact times for desorption kinetics and after $24 \mathrm{~h}$ for comparing the efficiency of desorption agents. For the study of metal desorption and sorbent recycling a washing step (pumping $50 \mathrm{~mL}$ of demineralized water) was intercalated between the desorption and the sorption steps; desorption efficiency was calculated comparing the amount of metal adsorbed on the sorbent at the preceding step with the metal released during the relevant desorption step.

Specific experiments were performed in direct flow mode (single-pass flow-through experiments) at a low flow rate (i.e., $0.2 \mathrm{~mL} \mathrm{~min}^{-1}$ ) to simulate fixed-bed system: a sample collector was connected to the outlet of the immobilized discs.

All the solution pHs were adjusted to 2.5 during sorption process, according to results obtained from batch experiments with beads prepared with the same materials [29]. Full experimental conditions are systematically reported in the caption of the Figures.

\subsection{Modeling of sorption isotherms and uptake kinetics}

Uptake kinetics have been modeled using both the pseudo-first order rate equation (PFORE) [39], and the pseudo-second order rate equation (PSORE) [40].

PFORE : $\quad q(t)=q_{e q}\left[1-e^{-k_{1} t}\right]$

PSORE : $\quad q(t)=\frac{q_{e q}^{2} k_{2} t}{1+q_{e q} k_{2} t}$

with; $\mathrm{q}_{\mathrm{t}}$ and $\mathrm{q}_{\mathrm{eq}}\left(\mathrm{mg} \mathrm{g}^{-1}\right)$ : sorption capacities adsorbed at $\mathrm{t}$ and at equilibrium, respectively.

The parameters $k_{1}$ and $k_{2}$ are the rate constants of PFORE $\left(\mathrm{min}^{-1}\right)$ and PSORE $\left(\mathrm{g} \mathrm{mg}^{-1} \mathrm{~min}^{-1}\right)$, respectively.

It is noteworthy that the PFORE and PSORE models have been initially designed for the description of reaction kinetics in homogeneous systems. These equations are commonly used now for fitting uptake kinetics in heterogeneous systems. This means that the kinetic parameters $\left(\mathrm{k}_{1}\right.$ and $\left.\mathrm{k}_{2}\right)$ that can be derived from the mathematical fits should be considered as apparent rate coefficients that take into account the specific limitations associated to the mechanisms of resistance to diffusion (film diffusion, intraparticle diffusion). The parameters of PFORE and PSORE equations (i.e., qeq, $\mathrm{k}_{1}$ and $\mathrm{k}_{2}$ ) were determined by non-linear regression analysis using Mathematica software.

Sorption isotherms describe the distribution of metal ions between the liquid and the solid phases (when varying metal concentration in the system). They plot sorption capacity (i.e., $\mathrm{q}_{\mathrm{eq}}$ ) vs. residual metal concentration (i.e., $\mathrm{C}_{\mathrm{eq}}$ ). Several models have been used for describing sorption isotherms including the Langmuir equation and the Freundlich equation [41]. While the Langmuir equation is a mechanistic model based on the equaling of sorption and desorption rates at equilibrium the Freundlich equation is an empirical power-type equation that frequently does not fit asymptotical profiles (occurring in most cases in solid/liquid sorption systems).

Langmuir equation : $q_{e q}=\frac{q_{m} b C_{e q}}{1=b C_{e q}}$

Frequently the Langmuir equation fails to fit the experimental points in the zone of stronger curvature of the sorption isotherms; this is especially the case for sorbents having a high affinity for target metal. The Langmuir-Freundlich equation (also called Sips equation) can be alternatively used for describing these sorption isotherms.

Sips equation : $\quad q_{e q}=\frac{q_{m} K_{s} C_{e q}^{1 / n}}{1+K_{s} C_{e q}^{1 / n}}$

where $\mathrm{b}\left(\mathrm{L} \mathrm{mg}^{-1}\right)$ is the affinity coefficient and $\mathrm{q}_{\mathrm{m}}\left(\mathrm{mg} \mathrm{g}^{-1}\right)$ is the sorption capacity at saturation of the monolayer in the Langmuir equation and $1 / n$ is the heterogeneity factor, $\mathrm{q}_{\mathrm{m}}$ the total number of binding sites, and $\mathrm{K}_{\mathrm{s}}\left(\mathrm{L} \mathrm{mg}^{-1}\right)$ the Sips affinity coefficient in the Sips equation. The parameters of the Langmuir and Sips equations (i.e., $\mathrm{q}_{\mathrm{m}}, \mathrm{b}, \mathrm{K}_{\mathrm{s}}$ and $\mathrm{n}$ ) were also obtained by non-linear regression analysis using Mathematica software.

\section{Results and discussion}

\subsection{Characterization}

Table S1 (see Supplementary Information) gives the measured values of the porosity of each sample: $90.9,93.2$ and $88.9 \%$ for alginate, $A B$ and $A B / P E I$ discs, respectively. Due to the incorporation of GLA-PEI, the bulk density of the composite is the highest 
$\left(0.039 \mathrm{~g} \mathrm{~cm}^{-3}\right)$, whereas no significant difference is found between alginate and $A B$ discs ( 0.031 and $0.032 \mathrm{~g} \mathrm{~cm}^{-3}$, respectively). Moreover, the $\mathrm{pH}_{\mathrm{ZPC}}$ is 4.45 for alginate, 5.09 for $\mathrm{AB}$ and 4.87 for $\mathrm{AB} / \mathrm{PEI}$ discs, suggesting that at a solution $\mathrm{pH}$ below these values (e.g. $\mathrm{pH}$ 2.5 in this study), the surface of the sorbents are positively charged and the electrostatic attraction should be one of the sorption mechanisms [42].

Fig. 1 shows the surface structure of the sorbents (Magnification: $\times 100)$. All the foam discs exhibit high toughness and a large internal porosity: the release of carbon dioxide bubbles from the reaction of calcium carbonate with formic acid during the preparation process contributes to the formation of large internal pores. Besides, all the sorbents possess an interconnected porous structure and this could be due to the freeze-drying process that may contribute to break some internal foils in the scaffold. The freezing of the materials caused the icing of water in the gel, which, in turn, contributes to the internal macroporosity [31]. It is noteworthy that the pores are homogeneously distributed over the surface, which well explains the high percolating property of the discs. Moreover, the structure of Pd-loaded discs appeared more compact and this trend became more obvious after desorption process, especially for $A B$ and $A B / P E I$ discs. This could be attributed to the impact of flow, which pressed the discs during sorption/desorption processes. However, significantly abundant pores could still be observed. This keeps the recirculation process running smoothly during the sorption/desorption cycles.

Figs. S1-S9 (see Supplementary Information) shows the EDX analysis and the map distribution of main elements for the raw,
Pd-loaded and Pd-desorbed discs. The raw sorbents (Fig. S1) are all characterized by the presence of $\mathrm{C}$ and $\mathrm{O}$ elements (organic tracers). Ca element is typically the tracer of the ionotropic gelation process. These elements are homogeneously distributed. Elements such as $\mathrm{S}$ and $\mathrm{Si}$ are also observed in $\mathrm{AB}$ and $\mathrm{AB} / \mathrm{PEI}$ discs. S element could be associated with sulfated polysaccharides such as fucoidans and carrageenans, which are commonly found in brown algae. A small amount of Si element is probably due to impurities and to the presence of diatomaceous residues. SEM-EDX shows that, after metal sorption, $\mathrm{Pd}(\mathrm{II})$ distribution is roughly homogeneous in the whole mass of the sorbents for alginate and $A B$ discs while in the case of $\mathrm{AB} / \mathrm{PEI}$, some large aggregates were formed. This is probably due to the accumulation of the metal on the small particles of GLA-PEI on the composite sorbents. $\mathrm{Cl}$ element, which is supposed to be associated with Pd element (probably under the forms of chloroanionic metal complexes), was clearly observed on Pdloaded sorbents, especially $\mathrm{AB}$ and $\mathrm{AB} / \mathrm{PEI}$ discs. Moreover, the dispersion of $\mathrm{Pd}$ element is much more correlated to $\mathrm{Cl}$ element on $\mathrm{AB} / \mathrm{PEI}$ and $\mathrm{AB}$ than on alginate discs: on alginate sorbent, a few small and isolated white spots mark the high density of $\mathrm{Cl}$ element while Pd element appears homogeneously distributed at the whole surface. This may explain the sorption mechanism: besides the ion exchange ( $\mathrm{Pd}(\mathrm{II})$ with $\mathrm{Ca}(\mathrm{II})$ ), the presence of a small amount of amide groups on protein in the inner cell wall of algal biomass and massive amine groups on GLA-PEI play an important role in binding Pd-chloro-anionic species through electrostatic attraction, which enhances the sorption capacity (see below). After desorption of Pd-loaded sorbents using $2 \mathrm{M} \mathrm{HCl} / 0.1 \mathrm{M}$ Thiourea $\left(\mathrm{NH}_{2} \mathrm{CSNH}_{2}\right)$,

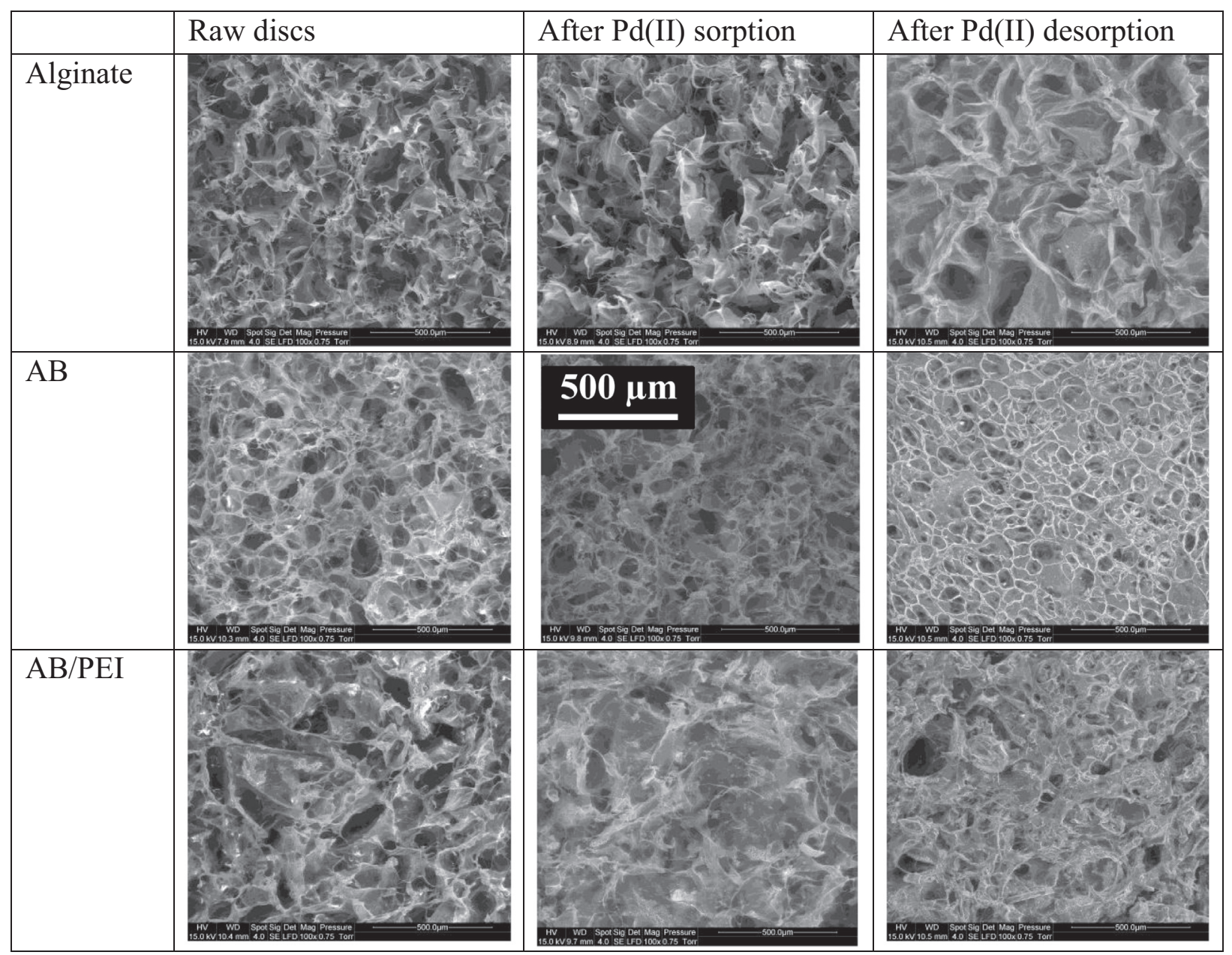

Fig. 1. SEM micrographs of alginate, $A B$ and $A B / P E I$ discs (raw, after Pd(II) sorption and after Pd(II) desorption) (Magnification: $\times 100$, common scale bar: $500 \mu m$ ). 
the elemental composition of the three types of foams greatly changed compared to the raw ones: the intensity of Ca peaks on the EDX analysis continuously decreases and strong signals of $\mathrm{S}$ and $\mathrm{Cl}$ elements appear. This change could be attributed to the calcium-proton exchange (due to $\mathrm{HCl}$ ) and simultaneous $\mathrm{Pd}$ desorption and modification by thiourea that brings more sulfur groups and amine groups [43]. As expected, no Pd peaks are found: the metal is readily desorbed with this eluent.

The corresponding FTIR spectra of these materials (raw, Pdloaded and Pd-desorbed) are shown in Fig. S10 (wavenumber range: $1800-400 \mathrm{~cm}^{-1}$, see Supplementary Information) and the assignments of the main bands in spectra are reported in Table S2 (wavenumber range: $4400-400 \mathrm{~cm}^{-1}$, see Supplementary Information). The Pd(II)-free spectra of the three raw sorbents present very similar profiles. The broad absorption peaks observed between $3500-3000 \mathrm{~cm}^{-1}$ and $3000-2850 \mathrm{~cm}^{-1}$ correspond to the overlapping of $-\mathrm{OH}$ or $-\mathrm{NH}$ peaks and $\mathrm{C}-\mathrm{H}$ stretching vibration, respectively. The peaks at $1592,1429,1025$ and $810 \mathrm{~cm}^{-1}$ represent COO- asymmetric stretching and symmetric stretching, C$\mathrm{O}-\mathrm{C}$ anti-symmetric stretching and $\mathrm{CH}_{2}$ rocking vibration, respectively. Besides, a peak at $1315 \mathrm{~cm}^{-1}$ corresponding to $\mathrm{C}-\mathrm{O}$ stretching is only found in alginate discs, while peaks at 1249 and $1162 \mathrm{~cm}^{-1}$, which are representative of $\mathrm{N}-\mathrm{H}$ stretching modes [44], are particularly observed in $\mathrm{AB} / \mathrm{PEI}$ composite. The presence of massive amine groups on $\mathrm{AB} / \mathrm{PEI}$ sorbent shows that, as expected, GLA-PEI has been successfully incorporated into $A B$, which can substantially improve its sorption capacity for $\mathrm{Pd}(\mathrm{II})$. It is noted that the peaks due to amine group vibration were not detected on $A B$ discs, probably due to the weak signal. Indeed, most of the brown algae possess a low protein content and for $L$. digitata, the value is as low as $2.6 \%$ [45].

After Pd(II) binding, the main changes are associated to slight shifts of the bands, such as at 3240,3260 and $3289 \mathrm{~cm}^{-1}$ (assigned to overlapping of $-\mathrm{OH}$ ) for alginate, $\mathrm{AB}$ and $\mathrm{AB} / \mathrm{PEI}$ discs, respectively, at $1595 \mathrm{~cm}^{-1}$ (for $A B$-based discs, assigned to $v_{\text {asymm }}(-$ COO-)) and at $1415 \mathrm{~cm}^{-1}$ (for all of the three, assigned to $\left.v_{\text {symm }}(\mathrm{COO}-)\right)$. Moreover, the disappearance of the peak at $1162 \mathrm{~cm}^{-1}$ (particularly found in $\mathrm{AB} / \mathrm{PEI}$ discs) confirms the involvement of amine groups in $\mathrm{Pd}(\mathrm{II})$ sorption onto $\mathrm{AB} / \mathrm{PEI}$ composite. In summary, hydroxyl, carboxyl groups in all the sorbents and amine groups in $\mathrm{AB} / \mathrm{PEI}$ sorbent are involved (as the main functional groups) in $\mathrm{Pd}(\mathrm{II})$ binding.

In the case of the Pd-desorbed sorbents, many changes show that the material was chemically modified by the desorption treatment. A new peak is appearing at $1727 \mathrm{~cm}^{-1}$ regardless of sorbents (assigned to $\mathrm{C}=\mathrm{O}$ stretching) while peak corresponding to COO- symmetric $\left(1429 \mathrm{~cm}^{-1}\right)$ stretching disappears; this is probably associated to the change of carboxyl group into carbonyl groups. In addition, the asymmetric stretching of COO- bond is shifted toward higher wavenumbers (i.e., 1656, 1650 and $1633 \mathrm{~cm}^{-1}$ for alginate, $A B$ and $A B / P E I$ discs, respectively). Other changes consist of the appearance of peaks at $1222 \mathrm{~cm}^{-1}$ for alginate and $1230 \mathrm{~cm}^{-1}$ for $A B$ discs (which was assigned to the stretching of $\mathrm{N}-\mathrm{H}$ bonds). This change can be explained by the use of thiourea in desorption agent, which could not only desorbed Pd(II) but also chemically modified the sorbents. Many researchers have used thiourea as a modification agent for improving the sorbent binding affinity toward precious metals (Pt(IV) or Pd(II)) [43,46]. Most of Pd(II) binding occurs through carboxylic/carboxylate groups on alginate and $\mathrm{AB}$ and amine groups on $\mathrm{AB} / \mathrm{PEI}$ discs; the succession of sorption/desorption steps affects the chemical structure of the sorbent (the decrease in carboxyl groups and appearance of amine and carbonyl groups). The sorption behavior of the three foams should be affected by such changes. Further experiments will confirm this hypothesis (see below: sorption-desorption cycles).

\subsection{Uptake kinetics}

The recirculation-mode sorption system proposed in this study requires a specific analysis of sorption kinetics concerning the necessity to force the solution flow through the highly porous discs and to ensure all the regions of the discs remain accessible. Therefore, the kinetic profiles (evolution of the residual concentration in the reactor) were compared under different flow rates: $5 \mathrm{~mL} \mathrm{~min}^{-1}, 25 \mathrm{ml} \mathrm{min}^{-1}$ and $45 \mathrm{~mL} \mathrm{~min}^{-1}$ (corresponding to superficial velocities of $0.61 \mathrm{~m} \mathrm{~h}^{-1}, 3.06 \mathrm{~m} \mathrm{~h}^{-1}$ and $5.51 \mathrm{~m} \mathrm{~h}^{-1}$, respectively). Fig. 2 shows that the flow rate hardly affects the kinetic profiles between 5 and $45 \mathrm{~mL} \mathrm{~min}^{-1}$ for all the sorbents, suggesting a slow flow rate $\left(5 \mathrm{~mL} \mathrm{~min}^{-1}\right)$ is already enough for making the solution entering the pore interiors from the pore surfaces. In general, alginate discs present the fastest sorption, followed by $A B$ and then $A B / P E I$ sorbents (this is also confirmed by the parameters of the pseudo-second order rate equation, see below). The different binding mechanisms could account for this phenomenon. Besides carboxyl groups on alginate, sulfonic acid groups on fucoidan (sulfated polysaccharide, $\mathrm{RO}^{-} \mathrm{SO}^{3-}$ ) and amide groups on protein could also play an important role in metal sorption onto algal-based sorbents [28]. On the other hand, $\mathrm{AB} / \mathrm{PEI}$ sorbent is more complex, possessing massive amine groups on GLAPEI. Therefore, the order of sorption rate (alginate $>A B>A B / P E I$ ) is probably due to that the binding between amine or sulfonic acid groups and palladium chloride complexes requires more time than the ion exchange between $\mathrm{Pd}(\mathrm{II})$ and $\mathrm{Ca}(\mathrm{II})$ or hydrogen ions. In addition, the mass transfer of metal species in GLA-PEI is probably controlled by intraparticle diffusion as a supplementary controlling step. Moreover, Fig. 2 also shows (taking flow rate $=45 \mathrm{~mL} \mathrm{~min}^{-1}$ as an example) that a pseudo-equilibrium is reached within the first $8 \mathrm{~h}$ of contact for alginate discs (the residual binding after $8 \mathrm{~h}$ of contact is less than $8 \%$ of total sorption), while for $\mathrm{AB}$ and $\mathrm{AB} / \mathrm{PEI}$ discs, these are $24 \mathrm{~h}$ and more than $48 \mathrm{~h}$, respectively.

The pseudo-second order rate equation (PSORE) and the pseudo-first order rate equation (PFORE) were tested for fitting kinetic profiles. Fig. 3 shows the kinetic modeling with the PSORE, while the fitting plots of PFORE are shown in Fig. S11 (see Supplementary Information). PSORE revealed more efficient for fitting the experimental profiles, with all the coefficient of determinations $\left(\mathrm{R}^{2}\right.$, shown in Table 1$)$ higher than 0.99 . This conclusion can also be confirmed by the comparison of estimated variances for PFORE and PSORE. However, while the predicted equilibrium sorption capacity (qeq,calc.) for alginate and AB discs (47.2 and $59.9 \mathrm{mg} \mathrm{g}^{-1}$,

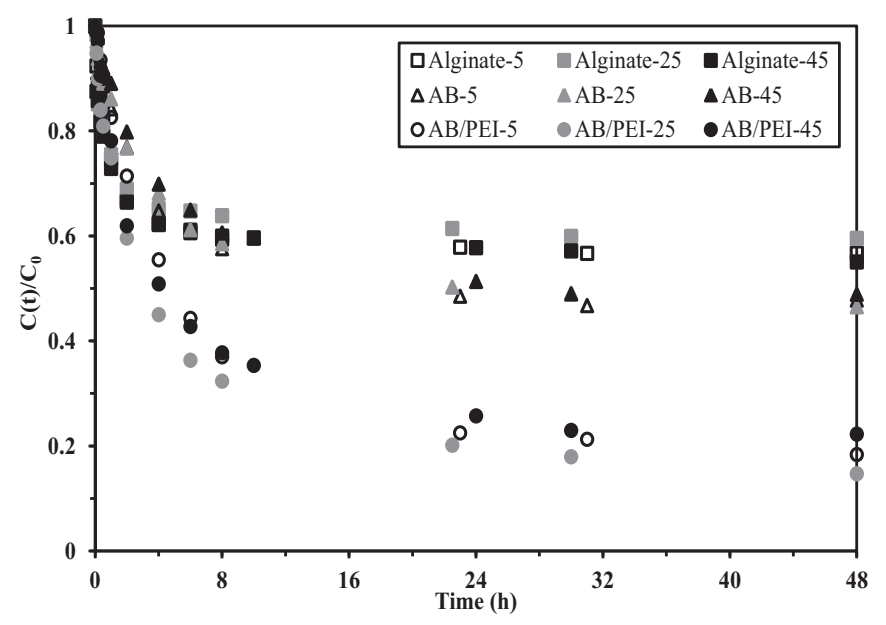

Fig. 2. Comparison of $P d(I I)$ uptake kinetics for alginate, $A B$ and $A B / P E I$ discs at different flow velocities ( $\mathrm{pH} 2.5 ; \mathrm{C}_{0}: 20 \mathrm{mg} \mathrm{Pd} \mathrm{L}^{-1} ; \mathrm{V}: 500 \mathrm{~mL} ; \mathrm{m}: 100 \mathrm{mg}$ (dry weight)). 

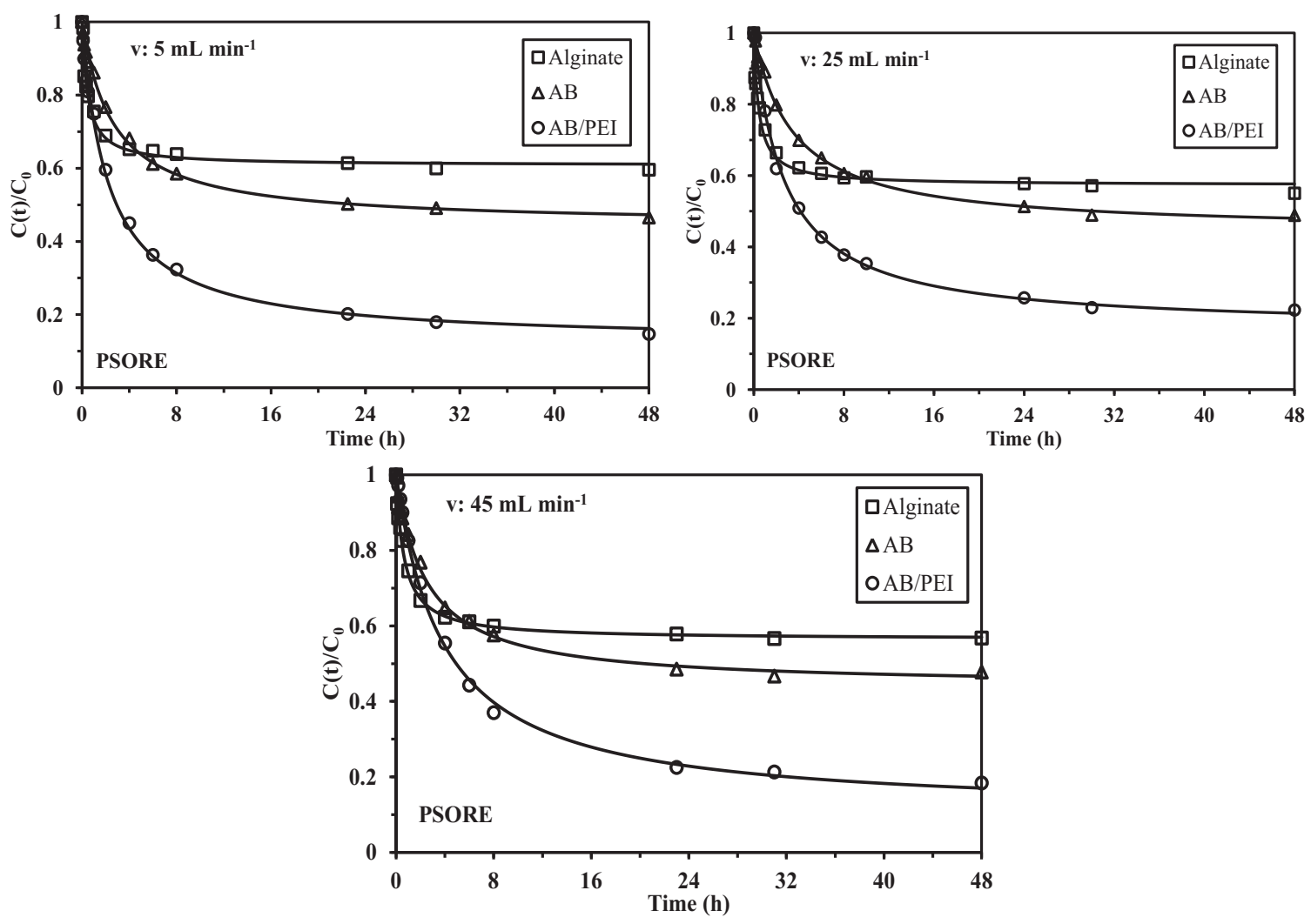

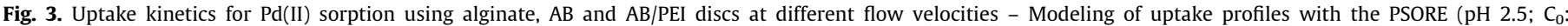
$20 \mathrm{mg}$ Pd L ${ }^{-1}$; V: $500 \mathrm{~mL}$; m: $100 \mathrm{mg}$ (dry weight)).

Table 1

Uptake kinetics - Modeling parameters for PFORE and PSORE (flow rate $=45 \mathrm{~mL} \mathrm{~min}{ }^{-1}$ ).

\begin{tabular}{|c|c|c|c|c|}
\hline Model & Parameter & Alginate & $\mathrm{AB}$ & $\mathrm{AB} / \mathrm{PEI}$ \\
\hline Experiment & $\mathrm{q}_{\mathrm{eq}, \exp }\left(\mathrm{mg} \mathrm{Pd} \mathrm{g^{-1 } )}\right.$ & 46.8 & 56.9 & 89.1 \\
\hline \multirow[t]{4}{*}{ PFORE } & $\mathrm{q}_{\text {eq,calc }}\left(\mathrm{mg} \mathrm{Pd} \mathrm{g}^{-1}\right)$ & 44.0 & 54.4 & 86.4 \\
\hline & $\mathrm{k}_{1} \times 10^{3}\left(\min ^{-1}\right)$ & 18.31 & 4.88 & 3.50 \\
\hline & $\mathrm{R}^{2}$ & 0.971 & 0.981 & 0.998 \\
\hline & EV & 8.11 & 9.07 & 2.63 \\
\hline \multirow[t]{4}{*}{ PSORE } & $\mathrm{q}_{\text {eq,calc }}\left(\mathrm{mg} \mathrm{Pd} \mathrm{g}^{-1}\right)$ & 47.2 & 59.9 & 97.9 \\
\hline & $\mathrm{k}_{2} \times 10^{4}\left(\mathrm{~g} \mathrm{mg}^{-1} \mathrm{~min}^{-1}\right)$ & 5.39 & 1.13 & 0.440 \\
\hline & $\mathrm{R}^{2}$ & 0.993 & 0.995 & 0.998 \\
\hline & EV & 1.94 & 2.42 & 2.11 \\
\hline
\end{tabular}

respectively) are close to the experimental values qeq,exp. (46.8 and 56.9 , respectively), the qeq,calc. $\left(98.9 \mathrm{mg} \mathrm{g}^{-1}\right)$ for $\mathrm{AB} / \mathrm{PEI}$ discs is overestimated comparing to $\mathrm{q}_{\mathrm{eq}, \exp }\left(89.1 \mathrm{mg} \mathrm{g}^{-1}\right)$. This could be due to the fact that $48 \mathrm{~h}$ of contact are not enough for $\mathrm{AB} / \mathrm{PEI}$ sorbents to reach the plateau. Indeed, by taking a closer look, $C(t) / C_{0}$ is found to continuously decrease between $30 \mathrm{~h}$ and $48 \mathrm{~h}$. The comparison of apparent rate coefficients again confirms the order of kinetic rate (in agreement with Fig. 2): alginate $>A B>A B / P E I$ with $\mathrm{k}_{1}$ of $18.31 \times 10^{-3}, 4.88 \times 10^{-3}$ and $3.50 \times 10^{-3} \mathrm{~min}^{-1}$, respectively, and $\mathrm{k}_{2}$ of $5.39 \times 10^{-4}, 1.13 \times 10^{-4}$ and $0.44 \times 10^{-4} \mathrm{~g} \mathrm{mg}^{-1}$ $\mathrm{min}^{-1}$, respectively. Great variation is found among previously reported experimental rate constants. Fujiwara et al. reported a pseudo second order rate constant of $0.0185 \mathrm{~g} \mathrm{mg}^{-1} \mathrm{~min}^{-1}$ [47], while Won et al. reported a rate constant of $0.063 \mathrm{~g} \mathrm{mg}^{-1} \mathrm{~min}^{-1}$ [48], both are two orders of magnitude greater than those found in this study. However, $\mathrm{k}_{2}$ can be affected by differing experimental conditions such as initial concentration, sorbent drying method, etc. [3], and it is rather difficult to identify precisely which condition contributes to the discrepancy between values obtained in this study and those in the literature since the sorption systems are different.

\subsection{Sorption isotherms}

The sorption isotherms represent the distribution of the solute between the liquid and solid phases for different solute concentrations. Langmuir and the Freundlich models are the most widely used equations for fitting these distribution curves. Judging from the asymptotic trend of uptake found in $\mathrm{Pd}(\mathrm{II})$ sorbed by the foam discs (Fig. 4), the Freundlich equation, which has an exponential form (power-type function), is apparently not suitable for fitting the sorption isotherms. Although the Langmuir equation fits the experimental curves for alginate and $A B$ sorbents well, it fails to predict the data obtained by $\mathrm{AB} / \mathrm{PEI}$ discs. Therefore, Sips equation was used. The Sips equation (also called Langmuir-Freundlich equation) introduces a supplementary parameter (i.e., n) that logically improves the quality of mathematical fit: all the experimental profiles (except for alginate) are fitted better by this equation and the estimated variances (EV) in Table 2 also confirm the great improvement in the fit of $\mathrm{AB} / \mathrm{PEI}$ composite data with a EV value of 20.36 while that achieved from Langmuir is as high as 174.5. The rank of sorption capacity is following the order: $A B /$ $\mathrm{PEI} \gg \mathrm{AB}>$ alginate. In this study, the $\mathrm{pH}$ was adjusted to $2.5 \mathrm{using}$ 

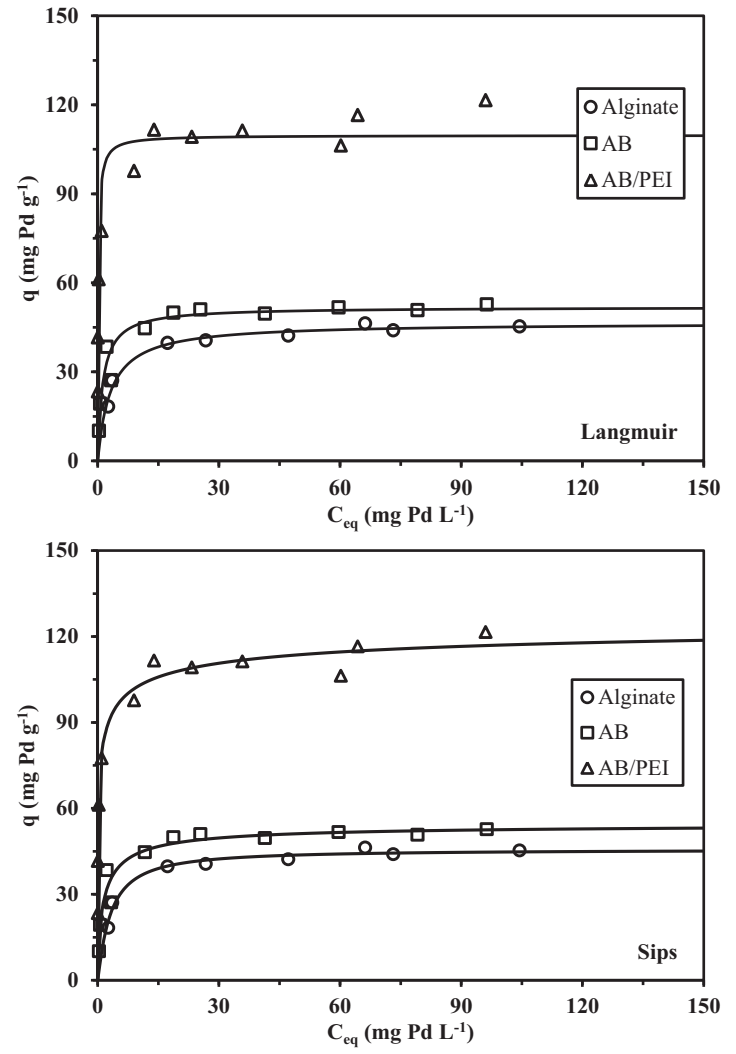

Fig. 4. $\mathrm{Pd}(\mathrm{II})$ sorption isotherms for alginate, $A B$ and $A B / P E I$ discs- Langmuir and Sips modeling ( $\mathrm{pH} 2.5 ; \mathrm{C}_{0}$ : 20-150 $\mathrm{mg} \mathrm{Pd} \mathrm{L}^{-1}$; Sorbent dosage (SD): $1 \mathrm{~g} \mathrm{~L}^{-1}$ for alginate and $\mathrm{AB}$ discs, $0.5 \mathrm{~g} \mathrm{~L}^{-1}$ for $\mathrm{AB} / \mathrm{PEI}$ discs (dry weight)).

$\mathrm{H}_{2} \mathrm{SO}_{4}$ or $\mathrm{NaOH}$ and the chloride concentration is low (the ratio of chloride and palladium ions in stock solution is $0.11 \mathrm{M} / 1 \mathrm{~g}$ ). The predominant $\mathrm{Pd}(\mathrm{II})$ species at low chloride concentration are $\mathrm{PdCl}_{2}\left(\mathrm{H}_{2} \mathrm{O}\right)_{2}(60 \%), \operatorname{PdCl}\left(\mathrm{H}_{2} \mathrm{O}\right)_{3}^{+}$and $\mathrm{PdCl}_{3}\left(\mathrm{H}_{2} \mathrm{O}\right)^{-}$[49]. The dissolving of $\mathrm{PdCl}_{2}$ in $\mathrm{HCl}$ for the preparation of stock $\mathrm{Pd}(\mathrm{II})$ solutions leads to the predominance of chloroanionic species: $\mathrm{PdCl}_{4}^{2-}$ (64.6\%), $\mathrm{PdCl}_{3}^{-}$ (25.4\%) and $\mathrm{PdCl}_{2}$ (aq) (Fig. S12, see Supplementary Information).

For alginate sorbent, the functional groups are carboxyl groups and the main sorption mechanism is limited to ion exchange between metal cations (i.e., $\mathrm{Pd}^{2+}, \mathrm{PdCl}^{+}$) and the protons on carboxylic groups or calcium ions bound to carboxyl groups [29], when the concentration of chloride ions is not high enough to displace the speciation to the formation of chloroanionic species. At low $\mathrm{pH}$, the competition of counter anions limits metal sorption. When the $\mathrm{pH}$ increases this competition effect decreases and metal species can be complexed on. When the concentration of chloride ions is high enough chloroanionic $\mathrm{Pd}(\mathrm{II})$ species are predominating and can be bound by electrostatic attraction. In the case of alginate the contribution is minimized since no reactive groups are directly available for binding these metal anions. It is noteworthy that $\mathrm{AB}$ discs exhibits a slightly higher sorption capacity although it possesses less content of carboxyl groups compared to pure alginate. In the case of $A B$, the presence of other carbohydrates, especially fucoidans that have a $\mathrm{pK}_{\mathrm{a}}$ close to 2 is more favorable for the binding of metal anions at $\mathrm{pH} 2.5$. The composition of $L$. digitata has been reported previously: $71.5 \%$ of carbohydrates, $2.6 \%$ of proteins, and about $0.9 \%$ of natural pigments (chlorophyll $a$, fucoxanthin, $\beta$ carotene and violaxanthin) plus about $15 \%$ of ashes (including metals) [45]. Thus, besides carboxyl groups on alginate, the sulfonic acid groups on fucoidan (sulfated polysaccharide, $\mathrm{RO}_{-} \mathrm{SO}_{3}-$ ) and amide groups on proteins could play an important role in binding $\mathrm{Pd}(\mathrm{II})$ through ion exchange and electrostatic attraction (binding chloro-anionic palladium species), respectively. On the contrary, for base metals (copper and lead), much higher sorption capacities of alginate than $A B$-based beads were found in the previous studies $[27,28]$. The results suggest that the sulfonic acid groups and amide groups are particularly effective in sorbing $\mathrm{Pd}(\mathrm{II})$, which is attributed to the softer character of $\mathrm{S}$ and $\mathrm{N}$-based ligands (compared to O-based ligands) [50]. This can also explain the much greater affinity of $\mathrm{AB} / \mathrm{PEI}$ discs (sorption capacity increases from 46.8 to $121.6 \mathrm{mg} \mathrm{g}^{-1}$ compared to $A B$ discs): the incorporation of $9 \%(w /$ w, d.w.) GLA-PEI improves more than $100 \%$ sorption property for $\mathrm{Pd}(\mathrm{II})$. Based on the equivalent sorption capacity attributable to the algal biomass fraction, which represents about $42.6 \mathrm{mg} \mathrm{g}^{-1}$, the fraction assigned to GLA-PEI should be close to $79.0 \mathrm{mg} \mathrm{g}^{-1}$ (i.e., $878 \mathrm{mg} \mathrm{g}^{-1}$ GLA-PEI). It is noteworthy that sorption isotherms performed on GLA-PEI powder showed maximum sorption capacities close to $790 \mathrm{mg} \mathrm{Pd} \mathrm{g}^{-1}$ (not shown); this is of the same order of magnitude taking into account the approximation in the actual content of GLA-PEI in the composite material. Polyethyleneimine is characterized by the presence of primary, secondary and tertiary amines with a wide range of $\mathrm{pK}_{\mathrm{a}} \mathrm{s}$. Incorporated in $\mathrm{AB} / \mathrm{PEI}$ sorbent, the protonation of some of these amine groups makes the sorbent cationic at mild acid $\mathrm{pH}$ and then capable of binding chloro-anions. The co-existence of free amine groups may also contribute to bind uncharged or free $\mathrm{Pd}(\mathrm{II})$ species; however, the strong predominance of chloro-anionic species limits the relevance of this mechanism. These sorption mechanisms have been more deeply discussed in a previous paper using the same materials conditioned under the form of spherical beads [29].

Table S3 (See Supplementary Information) reports Pd(II) sorption properties of a variety of materials. In general, chitosanbased sorbents, which bear amine groups, have higher binding affinity than other sorbents. Alginate and $A B$ discs show comparable (slightly higher) sorption levels with activated carbons [51], and much better than $\mathrm{Fe}_{3} \mathrm{O}_{4}$ nano-particles [52], melamine-formal dehyde-thiourea chelating resin [46], and aminated lignin [53], while $\mathrm{AB} / \mathrm{PEI}$ discs present similar sorption capacity with ethylenediamine-modified chitosan nanoparticles [54], and thiourea-modified chitosan microspheres [43]. Compared to chitosan or alginate, algal biomass-based sorbents are much more environmentally friendly. The one-pot synthesis, in which alginate

Table 2

Sorption isotherms - modeling parameters for Langmuir and Sips.

\begin{tabular}{|c|c|c|c|c|}
\hline Model & Parameter & Alginate & $\mathrm{AB}$ & $\mathrm{AB} / \mathrm{PEI}$ \\
\hline Experiment & $\mathrm{q}_{\mathrm{eq}, \exp }\left(\mathrm{mg} \mathrm{Pd} \mathrm{g}^{-1}\right)$ & 46.8 & 56.9 & 121.6 \\
\hline \multirow[t]{3}{*}{ Langmuir } & $\mathrm{q}_{\text {eq,calc }}\left(\mathrm{mg} \mathrm{Pd} \mathrm{g}^{-1}\right)$ & 46.5 & 51.8 & 109.7 \\
\hline & $\mathrm{b}\left(\mathrm{L} \mathrm{mg}^{-1}\right)$ & 0.313 & 0.788 & 5.78 \\
\hline & EV & 2.85 & 17.7 & 174.5 \\
\hline \multirow[t]{4}{*}{ Sips } & $\mathrm{q}_{\text {eq,calc }}\left(\mathrm{mg} \mathrm{Pd} \mathrm{g}^{-1}\right)$ & 45.7 & 54.7 & 129.1 \\
\hline & $\mathrm{b}\left(\mathrm{L} \mathrm{mg}^{-1}\right)$ & 0.281 & 0.744 & 1.55 \\
\hline & $\mathrm{n}$ & 0.89 & 1.32 & 2.52 \\
\hline & EV & 3.88 & 16.77 & 20.36 \\
\hline
\end{tabular}


is simultaneously extracted from the biomass itself and used for shaping/conditioning the sorbents, directly applies the biomass as "green alginate resource". This not only reduces the cost of the sorbents and the potential impact on the environment, but also makes these sorbents more readily available since the brown algae can be obtained from nature or cultivated easily and quickly in mass culture because of their short doubling time, suggesting the potential for practical application of such foam discs.

\subsection{Desorption and sorbent recycling}

Desorption process is very important for the sorbents concerning two aspects: reusing spent sorbents and concentrating the target metals in a smaller volume to achieve the practical application of recovery. Experiments were firstly carried out using various eluants. Fig. S13 (see Supplementary Information) shows that $2 \mathrm{M}$ $\mathrm{HCl} / 0.1 \mathrm{M}$ thiourea presents the best desorption effectiveness for all the sorbents: most of the $\mathrm{Pd}(\mathrm{II})$ was desorbed. The photographs in Fig. S14 (see Supplementary Information) vividly reveal the good desorption performance of the acidic thiourea for the three sorbents: the color after desorption process significantly becomes lighter. Indeed, the thiourea solution has already been described as an efficient eluent for $\mathrm{Pd}(\mathrm{II})$. Chassary et al. reported that using thiourea $(0.5 \mathrm{M})$ could achieve $88 \%$ desorption of $\mathrm{Pd}(\mathrm{II})$ from chitosan derivatives [55]. Ramesh et al. found acidic thiourea $(0.7 \mathrm{M}$ thiourea-2 $\mathrm{M} \mathrm{HCl}$ ) presented a better $\mathrm{Pd}(\mathrm{II})$ desorption efficiency of $98.27 \%$ [56]. Similarly, Fujiwara et al. concluded a comparable desorption performance of $0.7 \mathrm{M}$ Thiourea-2 $\mathrm{M} \mathrm{HCl}(99.98 \%)$ to $1 \mathrm{M} \mathrm{KCN}-0.5 \mathrm{M} \mathrm{NaOH}$ (99.44\%) for removing Pd(II) from L-lysine modified chitosan resin [47]. Based on the higher stability of alginate-based in acidic solutions compared to alkaline media, acidic-eluents are more appropriate.

The desorption kinetics shown in Fig. 5 suggest a fast desorption process for alginate discs: equilibrium has been obtained
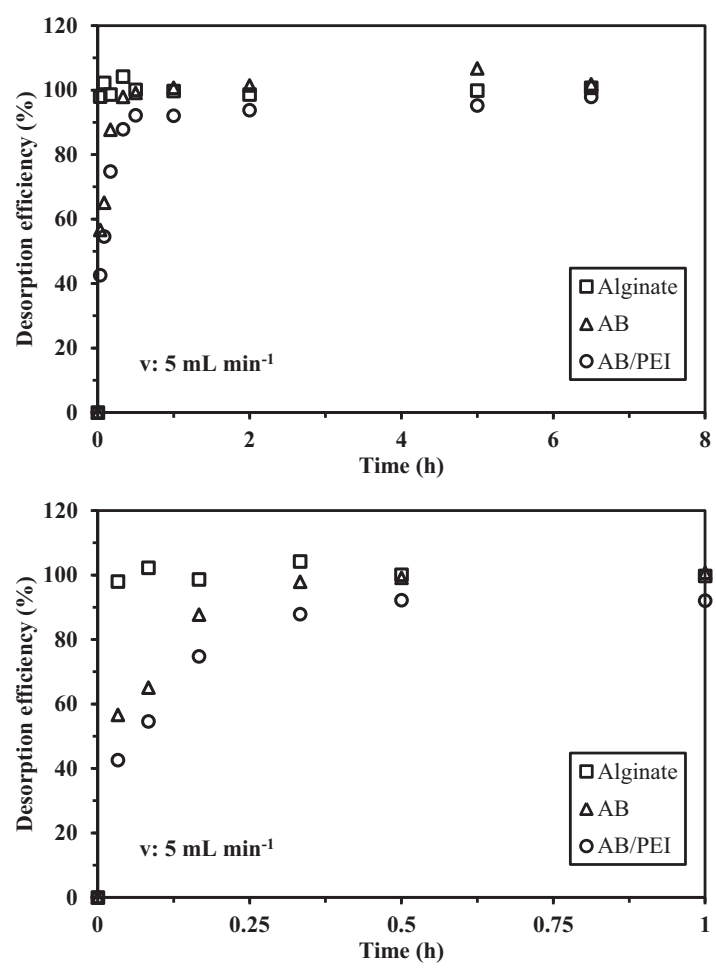

Fig. 5. $\mathrm{Pd}(\mathrm{II})$ desorption - desorption kinetics (Sorption step: $\mathrm{pH}$ 2.5; $\mathrm{C}_{0}$ : $20 \mathrm{mg} \mathrm{Pd} \mathrm{L}{ }^{-1}$; V: $500 \mathrm{~mL}$; m: $100 \mathrm{mg}$ (dry weight); Flow rate: $45 \mathrm{~mL} \mathrm{~min}^{-1}$; time: $48 \mathrm{~h}$ - desorption step: V: $500 \mathrm{~mL}$; Flow rate: $5 \mathrm{~mL} \mathrm{~min}^{-1}$ ). within the first $5 \mathrm{~min}$, while for $\mathrm{AB}$ sorbent, it increases to $0.5 \mathrm{~h}$ and $2 \mathrm{~h}$ for $\mathrm{AB} / \mathrm{PEI}$ composite. This could be explained by different sorption mechanisms of Pd(II) onto these three sorbents (see above discussion of sorption isotherm). The $\mathrm{Pd}(\mathrm{II})$ loaded through ion exchange with protons on carboxylic groups or calcium ions (bound to carboxyl groups) could be desorbed quickly, while those bound to sulfonic acid and amine groups require more desorption time.

In order to investigate the "desorption capacity" (i.e., the effect of metal-loaded amount on desorption efficiency), the spent sorbents obtained from the experiments of sorption isotherm were used for desorption. All the data points for alginate and $\mathrm{AB}$ discs lie on the first bisectrice in Fig. S15 (see Supplementary Information), suggesting that most of the metal ions could be removed by desorption even when the binding amount reaches maximum, and the same trend is observed for the composite sorbent $\mathrm{AB} / \mathrm{PEI}$ discs. Even for those points corresponding to high metal loading (i.e., higher than $110 \mathrm{mg} \mathrm{Pd}(\mathrm{II})$ per $\mathrm{g}$, where the sorption sites on $\mathrm{AB} / \mathrm{PEI}$ sorbents are mostly occupied), the desorption efficiencies are still higher than $92 \%$.

The results above confirm the high efficiency of acidic thiourea as an eluent solution. It was next used for investigating the reuse of the sorbents and the concentration factor of Pd(II). Fig. 6 shows the change in the sorption/desorption along 4 cycles of sorption/desorption with the 10-ratio of the volumes used for sorption and desorption steps (i.e., $\mathrm{V}_{\text {sorpt. }} / \mathrm{V}_{\text {des. }}$ : 10 for exploring the $\mathrm{Pd}(\mathrm{II})$ concentrating effect). The desorption efficiency of the three cycles for alginate and $\mathrm{AB}$ discs is around $90 \%$ and much less for $\mathrm{AB} / \mathrm{PEI}$ sorbents, which could be attributed to the high $\mathrm{Pd}(\mathrm{II})$ concentration in eluate (more than $100 \mathrm{mg} \mathrm{L}^{-1}$ in the first two cycles and $72 \mathrm{mg} \mathrm{L}^{-1}$ in the third cycle). Interestingly, an increase in the sorp-
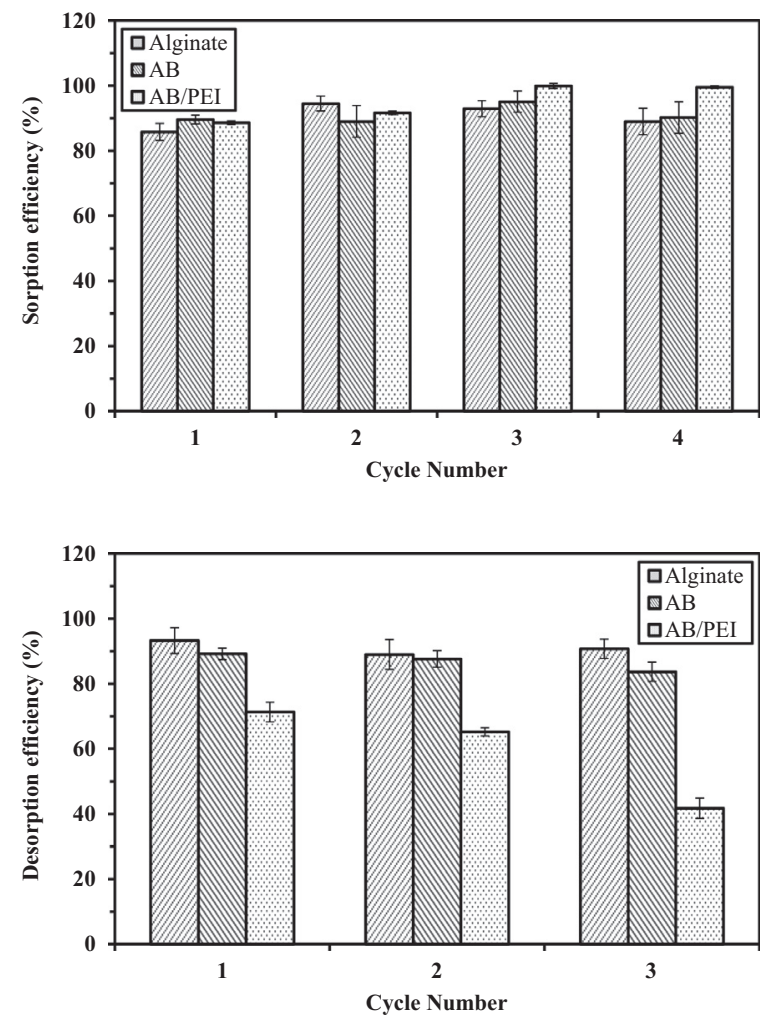

Fig. 6. $\mathrm{Pd}(\mathrm{II})$ sorption/desorption cycles - sorbent recycling (Sorption step: $\mathrm{pH} 2.5$; $\mathrm{C}_{0}$ : $17 \mathrm{mg} \mathrm{Pd} \mathrm{L}^{-1}$ for $\mathrm{AB} / \mathrm{PEI}$ and $9 \mathrm{mg} \mathrm{Pd} \mathrm{L}^{-1}$ for alginate and $\mathrm{AB}$ discs; V: $250 \mathrm{~mL}$; $\mathrm{m}$ : $50 \mathrm{mg}$ (dry weight); Flow rate: $5 \mathrm{~mL} \mathrm{~min}^{-1}$; time: $24 \mathrm{~h}$ - washing Step: $50 \mathrm{~mL}$ of demineralized water pumped through the discs - desorption step: $2 \mathrm{M} \mathrm{HCl} / 0.1 \mathrm{M}$

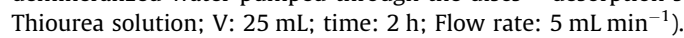


tion efficiency is found after desorption process, which is due to that during the desorption process, the acidic thiourea solution not only removed metal ions from the sorbents but also chemically modified the surface functional groups (i.e., amine groups, see characterization section). These groups are particularly effective in binding $\mathrm{Pd}(\mathrm{II})$. It should be mentioned that $\mathrm{Ca}(\mathrm{II})$ is released during the cycles (shown in Table S4, see Supplementary Information): around $70-75 \%$ of $\mathrm{Ca}$ (II) were released into the solution through ion exchange with $\mathrm{Pd}(\mathrm{II})$ during the sorption process in the first cycle and few $\mathrm{Ca}$ (II) release amount was found in further cycles, which means ion exchange with $\mathrm{Ca}$ (II) might be replaced by proton exchange for $\operatorname{Pd}(\mathrm{II})$ binding. With a $\mathrm{V}_{\text {sorpt. }} / \mathrm{V}_{\text {des. }}$ ratio of 10 , the concentration factor ( $\mathrm{CF}$, ratio of metal concentration in the eluate over its concentration in the sorption used for sorption) is 7.98.4 (data not shown) for alginate and 7.8-8.1 for $A B$, while for $\mathrm{AB} / \mathrm{PEI}$ discs the value decreases from 6.3 in the first cycle to 4.2 in the last cycle due to the reduction of desorption efficiency. In conclusion, alginate and $\mathrm{AB}$ sorbents can be applied successfully in recirculation mode and reused at least 4 times through sorption/desorption cycles with a $V_{\text {sorpt. }} / V_{\text {des. }}$ of 10 . Desorption efficiency remains more than $90 \%$ with no decrease in binding affinity when applied for the next sorption step. In the next step of the study, these materials are tested in a dynamic system (single-pass flow-through experiments) to extend the potential use of their practical application in metal recovery.

\subsection{Tests in dynamic systems: sorption and desorption}

In this section, as mentioned above, the immobilized discs were not fed in a recirculation mode but in a single-pass mode with a flow rate decreasing to $0.2 \mathrm{~mL} \mathrm{~min}^{-1}$, in order to offer sufficient contact time for the solution and the foam discs. It is noteworthy reminding in this context that the filtration bed consists of a single foam disc (m: $100 \pm 1 \mathrm{mg} ; \varnothing: 25 \mathrm{~mm}$; height: $2.6 \pm 0.2 \mathrm{~mm}$ ). Fig. 7 shows the breakthrough curves for Pd(II) sorption onto the sorbents: the relative metal concentration at the outlet of the foams and the cumulative amount of $\mathrm{Pd}$ (II) bound to the foams are plotted against volume. The sorption capacity calculated by the mass balance gives a sorption capacity approximate 38, 56 and $80 \mathrm{mg} \mathrm{Pd} \mathrm{g}^{-1}$ for alginate, AB and AB/PEI discs, respectively. Several models such as the Thomas equation [57], and the AdamsBohart model have been applied for the modeling the breakthrough [58]. Yan et al. suggest using an alternative model based on logistic function for getting a better approximation of the beginning and ending parts of the breakthrough curves [59]. The socalled Yan equation (reported in Supplementary Information [60]) predicts well the data for all the curves obtained by the three types of discs (especially for alginate and $\mathrm{AB} / \mathrm{PEI}$ ). The $\mathrm{q}_{\mathrm{y} a n}$ calculated is $42.8 \mathrm{mg} \mathrm{g}^{-1}$ for alginate, $46.7 \mathrm{mg} \mathrm{g}^{-1}$ for $A B$ and $89.4 \mathrm{mg} \mathrm{g}^{-1}$ for $\mathrm{AB} / \mathrm{PEI}$ discs. Compared those to experimental values, the slight decrease for alginate and $A B / P E I$ discs is observed. This could be due to the incomplete saturation of the sorbents.

Again, the acidic thiourea ( $2 \mathrm{M} \mathrm{HCl} / 0.1 \mathrm{M}$ Thiourea) was used for metal desorption from the foam discs in the dynamic system. Fig. 8 suggests that after passing $45 \mathrm{~mL}$, the amount of Pd(II) desorbed reaches a steady-state plateau and the corresponding Pd (II) concentration in the eluate is $81 \mathrm{mg} \mathrm{L}^{-1}$, while these are $80 \mathrm{~mL}\left(60 \mathrm{mg} \mathrm{L}^{-1}\right)$ and $50 \mathrm{~mL}\left(86 \mathrm{mg} \mathrm{L}^{-1}\right)$ for $\mathrm{AB}$ and $\mathrm{AB} / \mathrm{PEI}$ discs, respectively. This means the $\mathrm{CFs}$ are around $5.8,4.4$ and 6.1 for alginate, $A B$ and $A B / P E I$ sorbents, respectively. All of the foam discs show a good desorption performance: almost $100 \%$ of desorption efficiency is achieved for alginate and $95 \pm 1 \%$ for $A B$ and $A B / P E I$ discs. The continuous mode reveals quite efficient for $\mathrm{Pd}(\mathrm{II})$ sorption, desorption and concentration of $\mathrm{Pd}(\mathrm{II})$ using a low flow rate (i.e., $0.2 \mathrm{~mL} \mathrm{~min}^{-1}, 12 \mathrm{~mL} \mathrm{~h}^{-1}$ and superficial flow velocity close to $2.44 \times 10^{-2} \mathrm{~m} \mathrm{~h}^{-1}$ ).
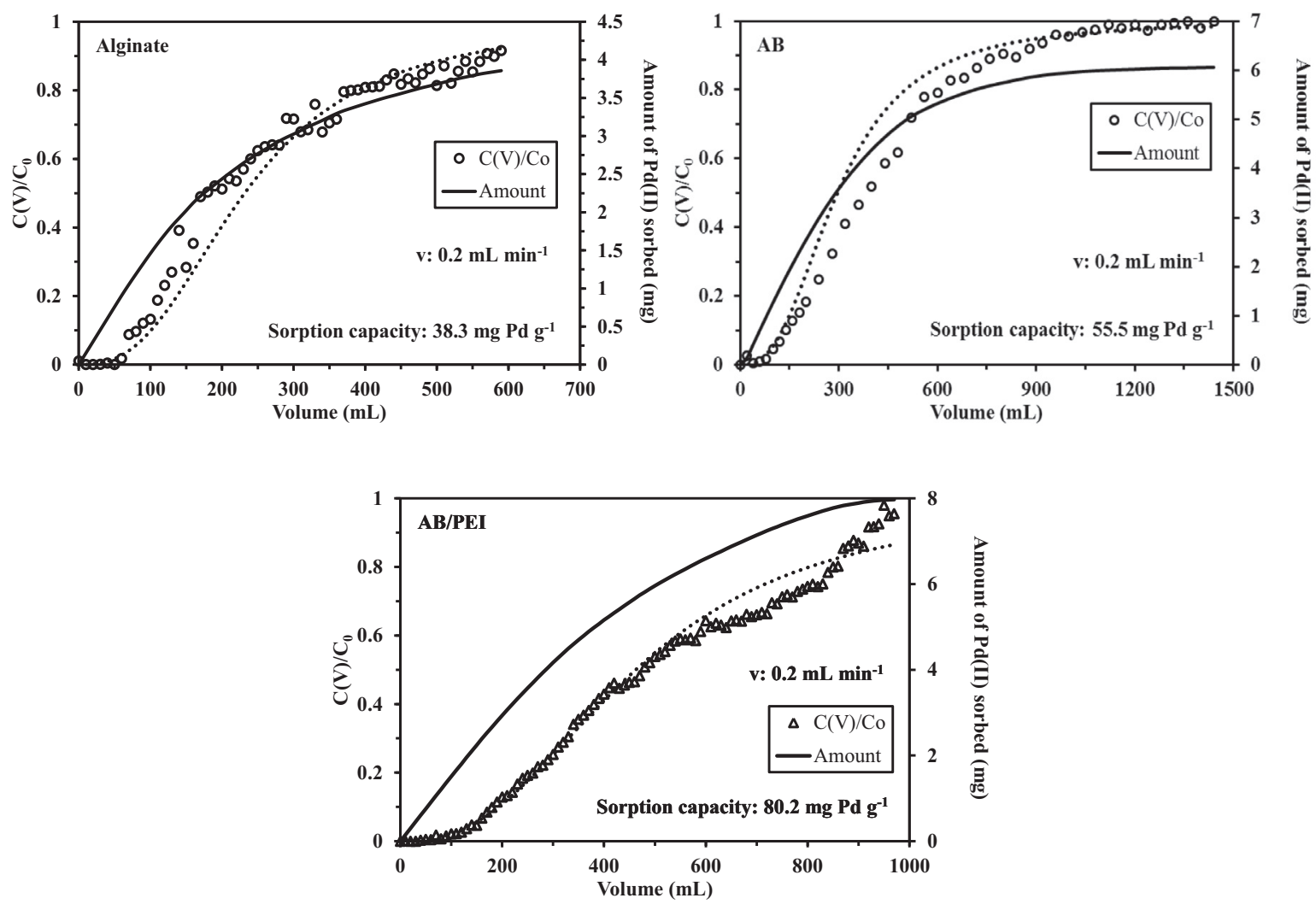

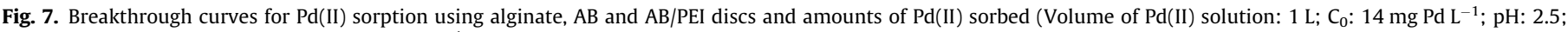
mass of sorbent: $100 \mathrm{mg}$; Flow rate: $0.2 \mathrm{~mL} \mathrm{~min}^{-1}$; dotted line: modeling of breakthrough with the Yan et al. model, [59]). 

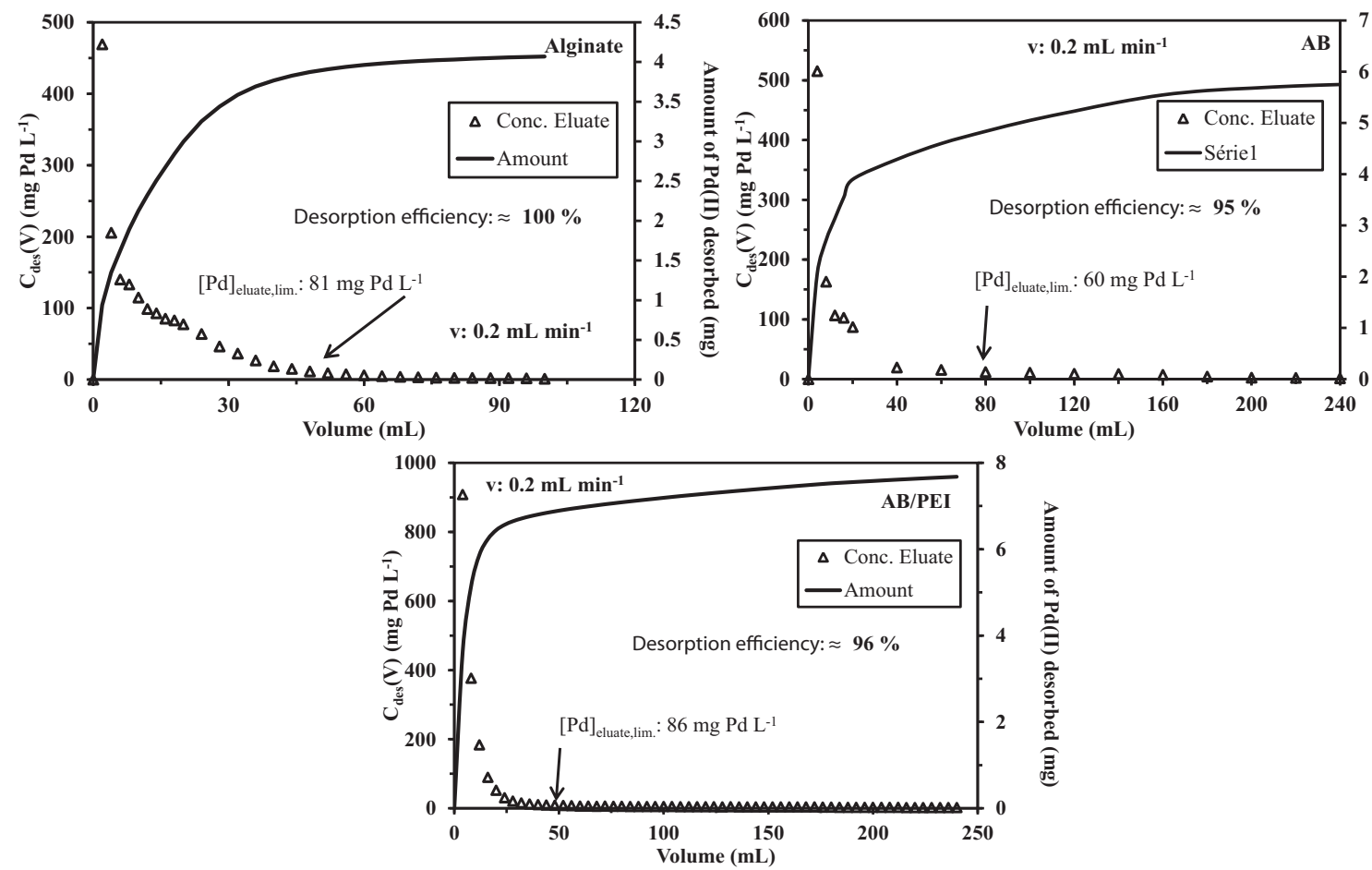

Fig. 8. Desorption curve for the recovery of $\mathrm{Pd}(\mathrm{II})$ from metal-loaded sorbents $(2 \mathrm{M} \mathrm{HCl} / 0.1 \mathrm{M}$ Thiourea solutions).

\section{Conclusions}

Porous algal biomass $(\mathrm{AB})$ discs were greenly prepared by onepot synthesis procedure. Glutaraldehyde-crosslinked polyethyleneimine (GLA-PEI) was incorporated into AB discs. The sorption properties of these two sorbents for palladium are compared with alginate discs (as a reference) in a fixed-bed like system using a recirculation mode or a single-pass mode. The flow rate shows no significant difference in sorption kinetic files of the sorbents: suggesting a slow flow rate $\left(5 \mathrm{~mL} \mathrm{~min}^{-1}\right)$ is already enough for making the solution entering the pore interiors from the pore surfaces. The incorporation of GLA-PEI markedly improves the sorption capacity of $A B$ discs since it brings a massive amount of amine groups, which are more reactive for $\mathrm{Pd}(\mathrm{II})$ binding than the main functional groups (carboxyl groups) on alginate and $A B$ discs. The kinetic profiles can be well fitted by the pseudosecond order rate equation. Sorption isotherms of $\mathrm{Pd}(\mathrm{II})$ onto alginate and $A B$ discs are well described by the Langmuir equation, while for that onto $\mathrm{AB} / \mathrm{PEI}$ discs, the Sips model (with a larger number of fitting parameters) is more appropriate. In the single-pass mode, the so-called Yan equation fits well the breakthrough curves, regardless of sorbent type. The Pd-loaded discs can be desorbed using acidic thiourea with a slight increase in sorption property, suggesting that the desorption agent simultaneously desorbs the target metal and chemically modifies the sorbents (bringing amine groups). All the sorbents can be reused for at least 4 times with a concentration factor ranging between 4 and 8 (depending on experimental conditions). To conclude, the greenly prepared $A B$ and $A B / P E I$ discs are effective in $\mathrm{Pd}(\mathrm{II})$ recovery when applied in the fixed-bed like systems with high sorption capacity and satisfactory concentrating factors.

Although the sorption capacities of these materials are lower than those of more conventional sorbents, the low cost of these sorbents, their recycling properties make them attractive for the treatment of dilute solutions. This study is complementary to other investigations performed on $\operatorname{Pr}(\mathrm{III})$ and $\mathrm{Pb}(\mathrm{II})$ sorption (in progress): the incorporation of PEI allows significantly improving sorption capacities for $\mathrm{Pd}(\mathrm{II})$, contrary to $\mathrm{Pb}(\mathrm{II})$, for example. The design of these sorbents as macro-porous foams is opening the way to alternative mode of utilization such as reactive filtration (making profit of the high percolating characteristics of these materials). The concept was also used for designing reactive sponges for the recovery of radionuclides: Prussian blue is immobilized into chitin sponges that can absorb contaminated water; after radionuclide transfer from to the solution to the ionexchanger, the wringing of the foam releases the decontaminated water [34].

As a perspective, these materials could find further application as Pd-loaded supported catalysts. The use of Pd-loaded sorbents (after metal reduction) is currently investigated for simple hydrogenation reactions.

\section{Acknowledgements}

Shengye Wang acknowledges the China Scholarship Council (CSC, Grant $N^{\circ}$ 20156660002) for providing fellowship. Thierry Vincent and Eric Guibal acknowledge European Union's Seventh Framework Programme (FP7/2007-2013) since these results are indirectly derived from a research project (BIOMETAL-DEMO) funded by the FP7 Programme managed by REA-Research Executive Agency (http://ec.europa.eu/research/rea) under Grant $\mathrm{N}^{\circ}$ 699101.

\section{Appendix A. Supplementary data}

Supplementary data associated with this article can be found, in the online version, at http://dx.doi.org/10.1016/j.cej.2017.05.103.

\section{References}

[1] A. Cieszynska, M. Wiśniewski, Extractive recovery of palladium(II) from hydrochloric acid solutions with Cyphos ${ }^{\circledR}$ IL 104, Hydrometallurgy 113-114 (2012) 79-85. 
[2] B. Gupta, I. Singh, Extraction and separation of platinum, palladium and rhodium using Cyanex 923 and their recovery from real samples, Hydrometallurgy 134 (2013) 11-18.

[3] A. Parodi, T. Vincent, M. Pilsniak, A.W. Trochimczuk, E. Guibal, Palladium and platinum binding on an imidazol containing resin, Hydrometallurgy 92 (2008) $1-10$.

[4] R. Navarro, I. Saucedo, C. Gonzalez, E. Guibal, Amberlite XAD-7 impregnated with Cyphos IL-101 (tetraalkylphosphonium ionic liquid) for Pd(II) recovery from $\mathrm{HCl}$ solutions, Chem. Eng. J. 185 (2012) 226-235.

[5] K. Kondo, M. Sawada, M. Matsumoto, Adsorption and separation of palladium and platinum with microcapsules containing tri-n-octylamine hydrochloride, J. Water Process Eng. 1 (2014) 115-120.

[6] C. Fontas, E. Antico, F. Vocanson, R. Lamartine, P. Seta, Efficient thiacalix[4] arenes for the extraction and separation of $\mathrm{Au}(\mathrm{III}), \mathrm{Pd}(\mathrm{II})$ and $\mathrm{Pt}(\mathrm{IV})$ metal ions from acidic media incorporated in membranes and solid phases, Sep. Purif. Technol. 54 (2007) 322-328.

[7] T. Vincent, A. Parodi, E. Guibal, Immobilization of Cyphos IL-101 in biopolymer capsules for the synthesis of Pd sorbents, React. Funct. Polym. 68 (2008) 1159 1169.

[8] S. Sharma, C.-M. Wu, R.T. Koodali, N. Rajesh, An ionic liquid-mesoporous silica blend as a novel adsorbent for the adsorption and recovery of palladium ions, and its applications in continuous flow study and as an industrial catalyst, RSC Adv. 6 (2016) 26668-26678.

[9] M. Regel-Rosocka, M. Rzelewska, M. Baczynska, M. Janus, M. Wiśniewski, Removal of palladium(II) from aqueous chloride solutions with cyphos phosphonium ionic liquids as metal ion carriers for liquid-liquid extraction and transport across polymer inclusion membranes, Physicochem. Prob. Miner. Process. 51 (2015) 621-631.

[10] Y. Hu, X. Wang, Y. Zou, T. Wen, X. Wang, A. Alsaedi, T. Hayat, X. Wang, Superio sorption capacities of $\mathrm{Ca}-\mathrm{Ti}$ and $\mathrm{Ca}-\mathrm{Al}$ bimetallic oxides for $\mathrm{U}$ (VI) from aqueous solutions, Chem. Eng. J. 316 (2017) 419-428.

[11] X. Ruan, Y. Chen, H. Chen, G. Qian, R.L. Frost, Sorption behavior of methyl orange from aqueous solution on organic matter and reduced graphene oxides modified Ni-Cr layered double hydroxides, Chem. Eng. J. 297 (2016) 295-303.

[12] Y. Yan, Q. An, Z. Xiao, W. Zheng, S. Zhai, Flexible core-shell/bead-like alginate@ PEI with exceptional adsorption capacity, recycling performance toward batch and column sorption of Cr (VI), Chem. Eng. J. 313 (2017) 475-486.

[13] A. Turner, M.S. Lewis, L. Shams, M.T. Brown, Uptake of platinum group elements by the marine macroalga, Ulva lactuca, Mar. Chem. 105 (2007) 271280.

[14] S. Morisada, Y.-H. Kim, T. Ogata, Y. Marutani, Y. Nakano, Improved adsorption behaviors of amine-modified tannin gel for palladium and platinum ions in acidic chloride solutions, Ind. Eng. Chem. Res. 50 (2011) 1875-1880.

[15] Z. Zhou, F. Liu, Y. Huang, Z. Wang, G. Li, Biosorption of palladium(II) from aqueous solution by grafting chitosan on persimmon tannin extract, Int. J. Biol. Macromol. 77 (2015) 336-343.

[16] I.S. Yunus, S.-L. Tsai, Designed biomolecule-cellulose complexes for palladium recovery and detoxification, RSC Adv. 5 (2015) 20276-20282.

[17] Q. Yi, R. Fan, F. Xie, Q. Zhang, Z. Luo, Recovery of palladium(II) from nitric acid medium using a natural resin prepared from persimmon dropped fruits residues, J. Taiwan Inst. Chem. Eng. 61 (2016) 299-305.

[18] E.S. Dragan, D.F.A. Loghin, A.I. Cocarta, Efficient sorption of $\mathrm{Cu}^{2+}$ by composite chelating sorbents based on potato starch-graft-polyamidoxime embedded in chitosan beads, ACS Appl. Mater. Interfaces 6 (2014) 16577-16592.

[19] X. Ju, K. Igarashi, S.-I. Miyashita, H. Mitsuhashi, K. Inagaki, S.-I. Fujii, H. Sawada, T. Kuwabara, A. Minoda, Effective and selective recovery of gold and palladium ions from metal wastewater using a sulfothermophilic red alga, Galdieria sulphuraria, Bioresour. Technol. 211 (2016) 759-764.

[20] E. Guibal, Interactions of metal ions with chitosan-based sorbents: a review, Sep. Purif. Technol. 38 (2004) 43-74.

[21] H. Sharififard, M. Soleimani, F.Z. Ashtiani, Evaluation of chitosan flakes as adsorbent for palladium and platinum recovery from binary dilute solutions, Int. J. Global Warming 6 (2014) 303-314.

[22] C. Zhu, F. Liu, Y. Zhang, M. Wei, X. Zhang, C. Ling, A. Li, Nitrogen-doped chitosan-Fe (III) composite as a dual-functional material for synergistically enhanced co-removal of $\mathrm{Cu}(\mathrm{II})$ and $\mathrm{Cr}(\mathrm{VI})$ based on adsorption and redox, Chem. Eng. J. 306 (2016) 579-587.

[23] S. Jia, Z. Yang, W. Yang, T. Zhang, S. Zhang, X. Yang, Y. Dong, J. Wu, Y. Wang, Removal of $\mathrm{Cu}$ (II) and tetracycline using an aromatic rings-functionalized chitosan-based flocculant: Enhanced interaction between the flocculant and the antibiotic, Chem. Eng. J. 283 (2016) 495-503.

[24] L.S. Rocha, Â. Almeida, C. Nunes, B. Henriques, M.A. Coimbra, C.B. Lopes, C.M. Silva, A.C. Duarte, E. Pereira, Simple and effective chitosan based films for the removal of Hg from waters: Equilibrium, kinetic and ionic competition, Chem. Eng. J. 300 (2016) 217-229.

[25] Y.N. Mata, M.L. Blazquez, A. Ballester, F. Gonzalez, J.A. Munoz, Biosorption of cadmium, lead and copper with calcium alginate xerogels and immobilized Fucus vesiculosus, J. Hazard. Mater. 163 (2009) 555-562.

[26] S. Cataldo, N. Muratore, S. Orecchio, A. Pettignano, Enhancement of adsorption ability of calcium alginate gel beads towards $\mathrm{Pd}(\mathrm{II})$ ion. A kinetic and equilibrium study on hybrid Laponite and Montmorillonite-alginate gel beads, Appl. Clay Sci. 118 (2015) 162-170.

[27] S. Wang, T. Vincent, C. Faur, E. Guibal, Alginate and algal-based beads for the sorption of metal cations: $\mathrm{Cu}(\mathrm{II})$ and $\mathrm{Pb}(\mathrm{II})$, Int. J. Mol. Sci. 17 (2016).
[28] S. Wang, T. Vincent, C. Faur, E. Guibal, Modeling competitive sorption of lead and copper ions onto alginate and greenly prepared algal-based beads, Bioresour. Technol. 231 (2017) 26-35.

[29] S.Y. Wang, T. Vincent, J.C. Roux, C. Faur, E. Guibal, Pd(II) and Pt(IV) sorption using alginate and algal-based beads, Chem. Eng. J. 313 (2017) 567-579.

[30] A.B. Hegge, T. Andersen, J. Melvik, S. Kristensen, H. Tønnesen, Evaluation of novel alginate foams as drug delivery systems in antimicrobial photodynamic therapy (aPDT) of infected wounds-an in vitro study: studies on curcumin and curcuminoides XL, J. Pharm. Sci. 99 (2010) 3499-3513.

[31] S.V. Madihally, H.W.T. Matthew, Porous chitosan scaffolds for tissue engineering, Biomaterials 20 (1999) 1133-1142.

[32] C. Vincent, Y. Barre, T. Vincent, J.M. Taulemesse, M. Robitzer, E. Guibal, ChitinPrussian blue sponges for $\mathrm{Cs}(\mathrm{I})$ recovery: From synthesis to application in the treatment of accidental dumping of metal-bearing solutions, J. Hazard. Mater. 287 (2015) 171-179.

[33] E. Guibal, S. Cambe, S. Bayle, J.-M. Taulemesse, T. Vincent, Silver/chitosan/cellulose fibers foam composites: From synthesis to antibacterial properties, J. Colloid Interface Sci. 393 (2013) 411-420.

[34] C. Vincent, A. Hertz, T. Vincent, Y. Barre, E. Guibal, Immobilization of inorganic ion-exchanger into biopolymer foams - Application to cesium sorption, Chem. Eng. J. 236 (2014) 202-211.

[35] D.J. McHugh, Production and utilization of products from commercial seaweeds. Chapter 2 - Production, properties and uses of alginates, in: FAO (Ed.), FAO Fisheries Technical Papers, FAO, Rome (Italy), 1987, pp. 58115.

[36] C. Bertagnolli, A.P.D.M. Espindola, S.J. Kleinuebing, L. Tasic, M.G. Carlos da Silva, Sargassum filipendula alginate from Brazil: Seasonal influence and characteristics, Carbohydr. Polym. 111 (2014) 619-623.

[37] P. Agulhon, M. Robitzer, L. David, F. Quignard, Structural regime identification in ionotropic alginate gels: Influence of the cation nature and alginate structure, Biomacromolecules 13 (2012) 215-220.

[38] M.V. Lopez-Ramon, F. Stoeckli, C. Moreno-Castilla, F. Carrasco-Marin, On the characterization of acidic and basic surface sites on carbons by various techniques, Carbon 37 (1999) 1215-1221.

[39] S. Lagergren, About the theory of so-called adsorption of soluble substances, Kungliga Svenska Vetenskapsakademiens 24 (1898) 1-39.

[40] Y.S. Ho, G. McKay, Pseudo-second order model for sorption processes, Process Biochem. 34 (1999) 451-465.

[41] C. Tien, Adsorption Calculations and Modeling, Butterworth-Heinemann, Newton, MA, 1994

[42] G. Moussavi, B. Barikbin, Biosorption of chromium (VI) from industrial wastewater onto pistachio hull waste biomass, Chem. Eng. J. 162 (2010) 893-900.

[43] L. Zhou, J. Liu, Z. Liu, Adsorption of platinum (IV) and palladium (II) from aqueous solution by thiourea-modified chitosan microspheres, J. Hazard. Mater. 172 (2009) 439-446.

[44] G. Ramis, M.A. Larrubia, An FT-IR study of the adsorption and oxidation of Ncontaining compounds over $\mathrm{Fe}_{2} \mathrm{O}_{3} / \mathrm{Al}_{2} \mathrm{O}_{3}$ SCR catalysts, J. Mol. Catal. A 215 (2004) 161-167.

[45] M.M. Nielsen, D. Manns, M. D’Este, D. Krause-Jensen, M.B. Rasmussen, M.M. Larsen, M. Alvarado-Morales, I. Angelidaki, A. Bruhn, Variation in biochemical composition of Saccharina latissima and Laminaria digitata along an estuarine salinity gradient in inner Danish waters, Algal Res. 13 (2016) 235-245.

[46] E. Birinci, M. Gülfen, A.O. Aydın, Separation and recovery of palladium (II) from base metal ions by melamine-formaldehyde-thiourea (MFT) chelating resin, Hydrometallurgy 95 (2009) 15-21.

[47] K. Fujiwara, A. Ramesh, T. Maki, H. Hasegawa, K. Ueda, Adsorption of platinum (IV), palladium (II) and gold (III) from aqueous solutions onto l-lysine modified crosslinked chitosan resin, J. Hazard. Mater. 146 (2007) 39-50.

[48] S.W. Won, J. Park, J. Mao, Y.-S. Yun, Utilization of PEI-modified Corynebacterium glutamicum biomass for the recovery of Pd (II) in hydrochloric solution, Bioresour. Technol. 102 (2011) 3888-3893.

[49] A. Uheida, M. Iglesias, C. Fontas, M. Hidalgo, V. Salvado, Y. Zhang, M. Muhammed, Sorption of palladium(II), rhodium(III), and platinum(IV) on $\mathrm{Fe}_{3} \mathrm{O}_{4}$ nanoparticles, J. Colloid Interface Sci. 301 (2006) 402-408.

[50] M.N. Hughes, R.K. Poole, Metal speciation and microbial growth-the hard (and soft) facts, Microbiology 137 (1991) 725-734.

[51] H. Sharififard, M. Soleimani, F.Z. Ashtiani, Evaluation of activated carbon and bio-polymer modified activated carbon performance for palladium and platinum removal, J. Taiwan Inst. Chem. Eng. 43 (2012) 696-703.

[52] A. Uheida, M. Iglesias, C. Fontàs, M. Hidalgo, V. Salvadó, Y. Zhang, M. Muhammed, Sorption of palladium (II), rhodium (III), and platinum (IV) on $\mathrm{Fe}_{3} \mathrm{O}_{4}$ nanoparticles, J. Colloid Interface Sci. 301 (2006) 402-408.

[53] D. Parajuli, H. Kawakita, K. Inoue, M. Funaoka, Recovery of gold (III), palladium (II), and platinum (IV) by aminated lignin derivatives, Ind. Eng. Chem. Res. 45 (2006) 6405-6412.

[54] L. Zhou, J. Xu, X. Liang, Z. Liu, Adsorption of platinum (IV) and palladium (II) from aqueous solution by magnetic cross-linking chitosan nanoparticles modified with ethylenediamine, J. Hazard. Mater. 182 (2010) 518-524.

[55] P. Chassary, T. Vincent, J.S. Marcano, L.E. Macaskie, E. Guibal, Palladium and platinum recovery from bicomponent mixtures using chitosan derivatives, Hydrometallurgy 76 (2005) 131-147. 
[56] A. Ramesh, H. Hasegawa, W. Sugimoto, T. Maki, K. Ueda, Adsorption of gold (III), platinum (IV) and palladium (II) onto glycine modified crosslinked chitosan resin, Bioresour. Technol. 99 (2008) 3801-3809.

[57] C. Xiong, J. Zhu, C. Shen, Q. Chen, Adsorption and desorption of praseodymium (III) from aqueous solution using D72 resin, Chin. J. Chem. Eng. 20 (2012) 823830.

[58] Y. Long, D. Lei, J. Ni, Z. Ren, C. Chen, H. Xu, Packed bed column studies on lead (II) removal from industrial wastewater by modified Agaricus bisporus, Bioresour. Technol. 152 (2014) 457-463.
[59] G.Y. Yan, T. Viraraghavan, M. Chen, A new model for heavy metal removal in a biosorption column, Adsorpt. Sci. Technol. 19 (2001) 25-43.

[60] C.K. Rojas-Mayorga, A. Bonilla-Petriciolet, F.J. Sanchez-Ruiz, J. Moreno-Perez, H.E. Reynel-Avila, I.A. Aguayo-Villarreal, D.I. Mendoza-Castillo, Breakthrough curve modeling of liquid-phase adsorption of fluoride ions on aluminumdoped bone char using micro-columns: Effectiveness of data fitting approaches, J. Mol. Liq. 208 (2015) 114-121. 